\title{
PANORAMA NOBILIARIO NAS TERRAS DE CAMBA E RODEIRO DESDE O TRÁNSITO Á IDADE MODERNA ${ }^{1}$
}

\author{
PANORAMA NOBILITY IN THE LAND OF CAMBA \\ AND RODEIRO IN TRANSIT TO MODERN AGE
}

CÉSAR GÓMEZ BUXÁN

\begin{abstract}
Resumo
Realizar un breve percorrido pola historia, xenealoxía e heráldica dos antigos liñaxes fidalgos da terra de Rodeiro desde a Idade Media é o obxectivo que finalmente se pretende. A evolución que comeza nas fortalezas medievais e continúa en torres de transición, remata nas residencias típicas da fidalguía, das que Trasulfe é o mellor expoñente. $\mathrm{Na}$ súa breve extensión o artigo tentará servir de guía ou iniciación a estudios máis detallados, necesarios para a comprensión da nosa historia, na que aparecen varios persoeiros con orixe nesta terra.
\end{abstract}

\section{Palabras clave}

Fidalguía, Camba, Rodeiro, fortalezas, xenealoxía, heráldica.

\begin{abstract}
To realize a small tour for the history, genealogy and heraldry of the former gentlemanly lineages of the land of Rodeiro from the Middle Ages is the aim that finally is claimed. The evolution that begins in the medieval fortresses and continues in towers of transition, finishes off in the typical residences of the nobility, of which Trasulfe is the best exponent. The article, in brief extension will try to use as guide or initiation to studies more detailed, necessary for the comprehension of our history, in which several prominent figures appear with origin in this land.
\end{abstract}

\section{Keywords}

Gentlemanly, Camba, Rodeiro, fortresses, genealogy, heraldry.

\footnotetext{
${ }^{1}$ Entregado en la revista el 25 de marzo de 2008.
} 


\section{INTRODUCCIÓN}

A historia dunha terra case sempre está ligada ós seus habitantes e, entre eles, dun xeito especial ós nobres, ben pola súa relevancia social e económica ou porque deixaron un máis abondoso testemuño nas fontes documentais, principalmente na época medieval.

Neste tempo as terras dominadas polo Faro teñen un vencello especial coa liñaxe homónima, os Rodeiro. A eles, e principalmente a Vasco Fernández de Rodeiro se debe, con case certa seguridade, a primitiva construcción das fortalezas de Rodeiro e Seoane de Camba, o que provocou nos séculos seguintes unha bicefalia, a coexistencia de dúas xurisdiccións independentes, vinculadas a cadansúa fortificación, demarcacións territoriais, xunto con outras desaparecidas no século XIX.

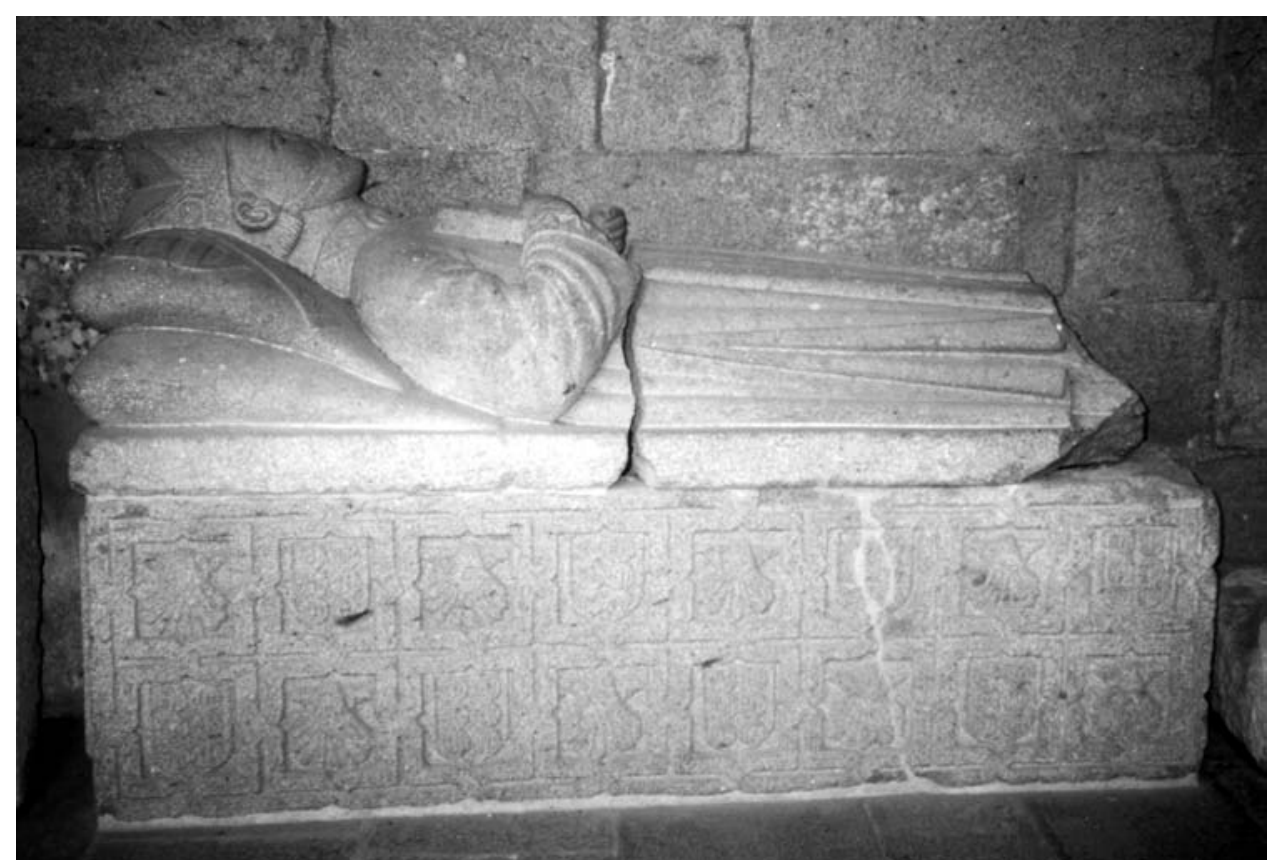

Figura 1: Sartego no claustro da catedral compostelá coas armas dos Rodeiro (seis rodas de carro).

Á beira destas testemuñas de poder como son as primitivas fortificacións medievais, vaise formando o xerme do que nos séculos XVII e XVIII configura o paradigma de residencia fidalga, os pazos. 
Pero a evolución en terras do interior como son as que conforman o concello de Rodeiro, coas súas características orográficas, climáticas e de poboación pasa por unha serie de fases ou niveis, desde a hexemonía indiscutible dunhas liñaxes (moi limitadas en número) que amosan o seu poderío e defenden o seu territorio mediante casas-fortes de variada tipoloxía, ata a época dourada dos fidalgos palacianos, estamento puramente rendista que procura traslada-la súa fachenda social ó plano arquitectónico, sen máis desexos que mante-la súa preeminencia.

No intermedio, unha figura artelladora, a do foro, contrato que permite que os grandes propietarios (a igrexa, principalmente en Rodeiro a mitra de Santiago, e os nobres titulados) deixen por un longo período de tempo a xestión das súas terras a outras persoas. A extracción social destes receptores de foros é diversa, pero principalmente os grandes beneficiados serán os pequenos fidalgos, escudeiros, escribáns, labradores acomodados, que co foro ven incrementa-las súas propiedades e os seus ingresos a troco dunhas rendas en moitos casos de pequena contía, coa posibilidade, amplamente empregada do "subforo", no que xa os recipientes acostuman ser pequenos campesiños que aboan unhas rendas sensiblemente superiores á primitiva, ocasionando con esto un "superávit" ó primeiro foreiro que posibilita o seu ascenso social e económico, orixe de moitos grandes patrimonios nestas terras.

Neste traballo imos tentar ofrecer unha visión moi xeral do que foi ó longo dos séculos o panorama das construccións fidalgas e de poder nas terras de Camba e Rodeiro, desde o tempo das fortalezas, en plena Idade Media (Rodeiro e Camba, esta última evolucionada en pazo), as torres xa sen función defensiva (Outeiro, Río, Guillar), as pousas e casas grandes (Vilar do Fondo, Salto, Fornas), ata chegar, como non, ós verdadeiros pazos (do que Trasulfe é o exemplo máis destacado).

\section{AS FORTALEZAS}

\section{II.1. Fortaleza de Rodeiro}

Posiblemente a súa orixe derive do privilexio outorgado por don Sancho, fillo do rei don Alonso, no 1282, pola que lle "da a Basco Fernández de Rodeiro, su vasallo, la Tierra de Camba, según parte con Asma, con Dorra y con Bentosa, con Deza y con Dozón, con el Volo de Senda, y con las Lamas de Aguada, y que las pudiese vender y enajenar, pero que no lo pudiese hacer de estas cosas con orden, ni con otro ninguno porque el Rey perdiese su derecho" 2 .

\footnotetext{
${ }^{2}$ Arquivo Histórico Universitario de Santiago (en adiante AHUS), Clero, Mitra 140.
} 


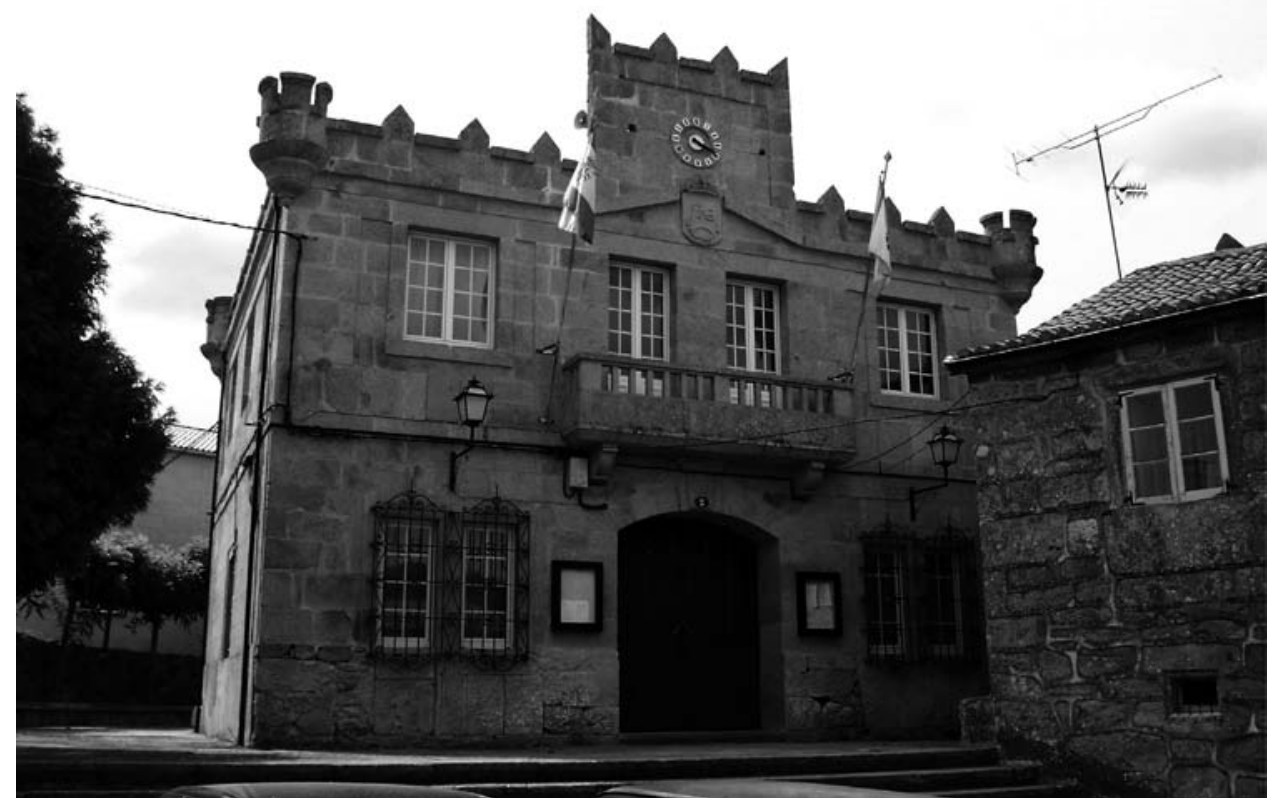

Figura 2: O actual concello de Rodeiro, levantado no mesmo lugar e a semellanza da fortaleza.

Desta estirpe dos Rodeiro eran Roi Fernández, que no 1247 figura como tenente en Camba, o seu irmán Munio Fernández, Malapel, meiriño maior da Galiza e mayordomo regis in Gallecia, e outro Munio Fernández, sobriño deles, tenente en Orcellón ${ }^{3}$.

O citado Vasco Fernández de Rodeiro, parente dos anteriores, agraciado coa terra de Camba, edificou posiblemente a fortaleza de Rodeiro, que máis adiante pasou ós Isorna e deles á Mitra de Santiago.

De diversas épocas conservamos descricións da antiga fábrica da fortaleza, máis ou menos detalladas. As máis antigas referencias se conteñen nunha das fontes máis importantes para o coñecemento das fortalezas da mitra compostelá no tránsito cara á Idade Moderna, o preito Tábera-Fonseca, no que se ofrecen variadas descricións da fortaleza de Rodeiro, dando resposta á pregunta número 20 do interrogatorio 4 .

\footnotetext{
${ }^{3}$ E. PARDO DE GUEVARA Y VALDÉS, "Parentesco y nepotismo. Los arzobispos de Santiago y sus vínculos familiares en los siglos XIV y XV", en Los coros de catedrales y monasterios: arte y liturgia [páxs. 65-119]. A Coruña. Fundación Pedro Barrié de la Maza, 2001. Páx. 71.

${ }^{4}$ A. RODRÍGUEZ GONZÁLEZ, Las Fortalezas de la mitra compostelana y los irmandiños: Pleito Tabera-Fonseca. 2 vol. Fundación Pedro Barrié de la Maza, Conde de Fenosa, A Coruña, 1984, páx. 29.
} 
En concreto contestan a ela, como testemuñas por parte do arcebispo de Santiago, Xácome de Marinaos ${ }^{5}$, Estevo Fariña ${ }^{6}$, Fernán de Santiago ${ }^{7}$, e Guillerme de Tristemill ${ }^{8}$. Tamén se refiren á fortaleza de Rodeiro dúas testemuñas por parte do arcebispo de Toledo, Vasco de Marzás ${ }^{9}$, e Alonso Yañez de Mellid ${ }^{10}$.

\section{II.1.1. A fortaleza de Rodeiro no século XV}

Cos datos que ofrecen as testemuñas pódese facer unha reconstrucción do aspecto exterior da fortaleza de Rodeiro, tanto no tempo anterior ós Irmandiños como despois deles.

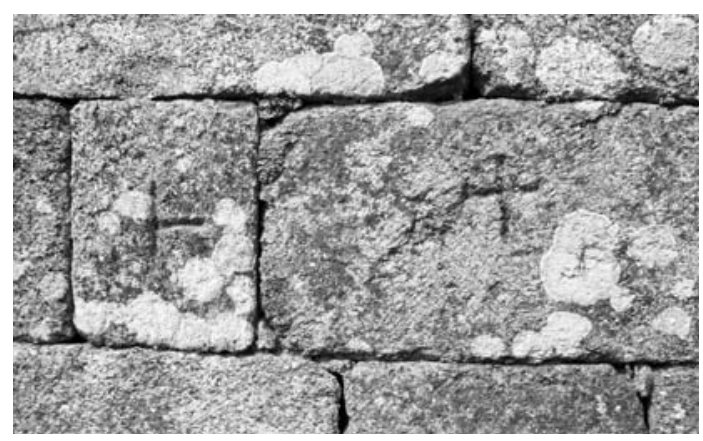

Figura 3: Signos lapidarios nos arredores.

O primeiro destacable ó se ir achegando ó recinto fortificado era o muro ou cerca que o rodea "alto e grueso que se andaba por ençima alderredor con su antepeito", que, segundo algunha testemuña "a paresçer del testigo tenia tres pies en ancho"11, con dúas portas, unha a chamada do "Pumar" e a outra na ponte do

\footnotetext{
5 Labrador, veciño e morador da freguesía de San Estevo de Carboentes, de 80 anos. RODRÍGUEZ, Op. cit., T. I, páxs. 171-172.

${ }^{6}$ Labrador, veciño e morador de Santa Baia de Camba, de 60 anos. RODRÍGUEZ, Op. cit., T. I, páxs. 173-174.

${ }^{7}$ Labrador, veciño de Santiago de Arnego, de 80 anos. RODRÍGUEZ, Op. cit., T. I, páx. 174-177.

${ }^{8}$ Posiblemente co apelido toponímico Cristimil, non Tristemill, xa que era veciño de San Cristovo do Az, freguesía na que existe o lugar de Cristimil. De 80 anos de idade. RODRÍGUEZ, Op. cit., T.I, páx. 177-178.

${ }^{9}$ Escudeiro, veciño do couto e mosteiro de Chantada, duns 70 anos. RODRÍGUEZ, Op. cit., T. II, páxs. 502-505.

${ }^{10}$ Veciño da freguesía de San Salvador de Camba, de idade "de más de cien años". RODRÍGUEZ, Op. cit., T. II, páxs. 505-508.

${ }^{11}$ Decl. de Guillerme de Tristemil, "e que la dicha çerca hera gruesa e fuerte que se andaba por ençima e que a paresçer del testigo ternia tres pies en ancho como quiera quel testigo no los medio".
} 
"Hespino", circundando un "corral" que se pechaba con "su puerta e llabe que se çerraba cada noche". Neste curral atopábase un (supoñemos) grande edificio, chamado o "palacio del arçobispo" ou "paaço del arçobispo", "sobradado con sus pieças de serbiçio y aposiento", e a casa do xuíz, ademais de seis ou sete casas onde vivían outros tantos peóns coas súas familias e a facenda para a súa mantenza. Eran algúns destes habitantes do curral da fortaleza García da Pena Herbosa, Gómez Arnarra e Lope da Portela. Todas estas casas do curral eran terreas, colmadas de colmo e de pedra e barro as súas paredes.

Ó cruza-lo curral, chegaríase ó foso ou "caba", "limpia y paredada de cantería $y$ argamasa alrededor", polo que botaban o río cando era necesario para incrementa-las defensas da fortaleza.

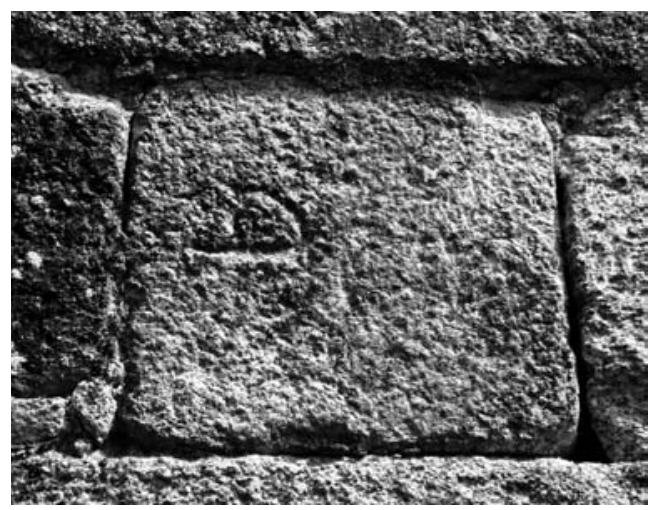

Figura 4: Outro signo nun sillar da antiga torre.

Despois do foso, o "incinto" fortificado, "con guirnalda y almena alderredor" polo que se accedía ó recinto central, defendido por una barbacá "alta y bien labrada $y$ enguirnaldada alderredor". Neste recinto estaba tamén, preto da torre, unha edificación que chamaban Paraíso, onde residían as mulleres dos alcaldes, ou, segundo algunhas testemuñas, o meiriño e alcaide da fortaleza ${ }^{12}$, así como o arcebispo cando acudía a Rodeiro, e no baixo había despensa, gardando nela froita e viño.

O centro de toda a fortificación era a "bara de casa" ou torre da homenaxe, feita de pedra de gran, alta, cuberta e tellada no medio, con muros rematados por merlóns e adornada cos seus cubos nas esquinas. Segundo algunha testemuña, estaba "texada y cubierta" e velábase arredor do guirnaldado e almenado.

12 Declaración de Xácome de Marinaos. 


\section{II.1.2. O final do século $X V$}

A revolución irmandiña afectou á fortaleza de Rodeiro, nembargantes, os veciños dela opuxéronse ó derrocamento da mesma cando chegaron as Irmandades ${ }^{13}$.

Afectouna este ataque destruíndo o coroamento dos seus muros e deixando a torre da homenaxe catro ou cinco fileiras de pedra máis baixa "según que al presente della paresçe" 14 . Así mesmo, a caída dos restos, destruíu parte do incinto, que tamén foi esmoucado "lo almenado e guirnaldado e los canes de la dicha guirnalda de algunas partes más e de otras menos, según que agora paresçe lo nuebo de lo biejo". Tamén o pequeno castelo da entrada "donde está la tulla del pan" sufriu os embates das irmandades, que a destruíron "desde la mas alta lunbrera que ella tiene arriba".

O relato máis extenso dos feitos corresponde á testemuña Alonso Yáñez de Mellid:

[...] en la dicha tierra [Camba] los vezinos della se juntaran en la dicha hermandad y que avia en ella tres alcaldes de hermandad que se llamaban Joan da Granxa y Joan Raton y Joan de Santiago, los quales heran alcaldes de la dicha hermandad en la dicha tierra de Canba y que los dichos alcaldes mandaban la gente de la dicha tierra y la dicha gente los obedesçia y azian lo que ellos mandaban e al dicho tienpo dize este dicho testigo que andando asi la dicha hermandad bio benir un alcalde de la dicha hermandad de la çiudad de Sanctiago que se llamaba Joan Ares Chantrero a su creer a la dicha fortaleza de Rodero que hes de la sancta Iglesia de Santiago e siendo alcalde della un Afonso Crespo, dize este testigo que la entregara al dicho alcalde de Santiago e quel dicho Alcalde la entregara a los alcaldes de la hermandad de la dicha tierra de Canba, los quales la entregaran a Basco Lopez de Cangas y el la resçibiera dellos y les feziera preitomenaje por ella y despues los de Santiago dize el testigo que demandaban la dicha fortaleza a los dichos alcaldes de tierra de Canba y ellos la demandaran al dicho Basco Lopez y el ge la entregara y los dichos alcaldes de tierra de Canba la entregaran a los dichos alcaldes de la dicha hermandad de la ciudad de Santiago, los quales con los de la tierra de Deza la derrocaron y desmocharon la dicha vara de casa y la çerca della por lo alto [...]

[...] que vido que despues de pasada la dicha hermandad que derroco las dichas fortalezas en el dicho Reino de Galiçia quel dicho señor Patriarca, siendo arçobispo de Santiago fiziera reparar y adresçar la dicha fortaleza de Rodeiro que avia sido

${ }^{13}$ Declaración de Fernán de Santiago "al tienpo que derrocaran la dicha fortaleza de Rodeiro los de la tierra requirieron que no se derrocase". Así mesmo a de Guillerme de Cristimil "binieron para derrocar la dicha fortaleza de Rodero la gente de la dicha tierra e basallos della se armaran e fueran contra ellos deziendo que ellos no abian de derrocar la dicha fortaleza porque no trayan ni tenian mandamiento real ni licençia sino que hera una locura".

${ }^{14}$ Declaracións de Fernán de Santiago e Guillerme de Tristemil. Na pregunta 20 do interrogatorio figura que a "vara de casa" tiña "quinze fileras alderredor en alto de más de las que agora están". 
derrocada por la dicha hermandad todo lo que aora paresçe que fue adresçado en ella de lo que fue derribado de la dicha fortaleza que fuera todo lo del ynçinto por lo alto del que hes lo aguinaldado que aora paresçe que fue fecho e demas dello fiziera llebantar un pedaço del castelete questa sobre la puerta por donde entran a la dicha fortaleza que fue labrado desde ençima de la dicha puerta y que la bara de casa quedara como esta y quedo desmochada y derrocada de la dicha hermandad [...]

Vemos que despois de rematado o movemento irmandiño o arcebispo Alonso de Fonseca fixo reparacións importantes na mesma, entre elas o incinto, máis fortificado que antes ${ }^{15}$. Tamén fixera "tornar adobar de la dicha çerca todo lo que paresçia agora que hesta fecho", así como "la sala del aposiento de la dicha casa".

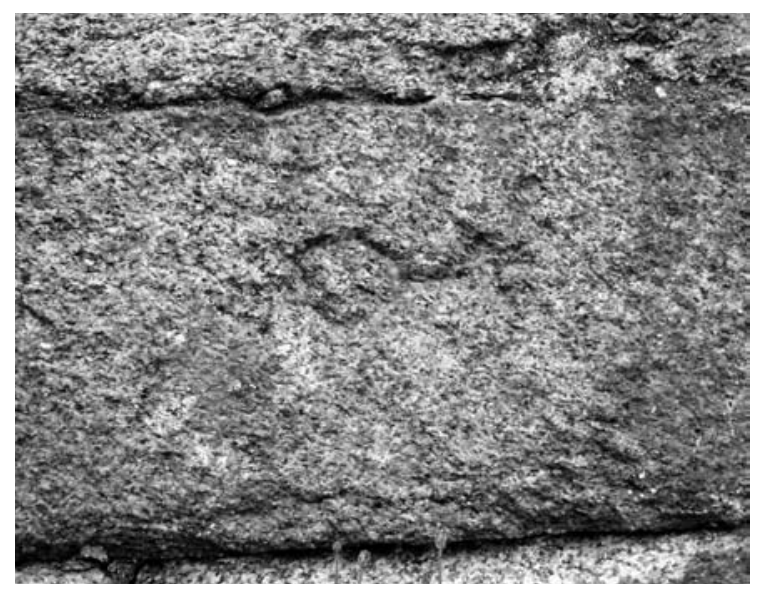

Figura 5: Aínda se conservan marcas dos canteiros.

Outro dos elementos que arranxou o arcebispo Fonseca foi "la torre que hesta sobre la puerta por donde entran a la dicha fortaleza" a metade superior dela, tal e como se atopaba na época do preito.

Para estes traballos enviou "ofiçiales de pedreros y carpinteros de Santiago", sen que "ninguno de los basallos de la dicha fortaleza para ello diese ni ayudase con ninguna cosa salbo que ayudaban a serbir en ella algunos dellos"16.

O palacio no curral da fortaleza ardeu, cubriuse despois e foi transformado en corte dos cabalos. Gómez Ares, meiriño da fortaleza, araba e pacía as herdades e

\footnotetext{
${ }^{15}$ Decl. de Xácome de Marinaos: "hera çercada de un ynçinto de la manera que el que agora tiene salbo que le paresçe quel que agora tiene hestá mas rezio".

16 Decl. de Alonso Yáñez de Mellid.
} 
montes que acostumaban levar aqueles seis ou sete labradores, que "se arredraran e dexaran las dichas casa e que no llebantaran mas las dichas casas ni çerca"17. As casas foran queimadas e despois volveron a erguerse, vivindo na época do preito, dous labradores dentro do dito curral e as outras casas convertéronse en cortes "donde el ganado se acoje", afirmando que o dito curral "está derrocado todo" ${ }^{18}$. Nestas dúas casas que se levantaran vivían en tempo do preito Fernán Calviño e Ares Cao.

\section{II.1.3. O século XVI}

A taxación de danos contida no preito Tabera-Fonseca ${ }^{19}$, levada a cabo en Rodeiro o 9 de setembro do 1526 polos peritos Xoán de Álava e Xoán Xil, indica unha cantidade de mil cincocentos marabedís para o arranxo da mesma. O primeiro que atopan é que faltaba o chan do segundo piso da torre principal, e que "avia menester diez tablones para lo tornar a solar, porque las vigas prinçipales las tyene buenas". Así mesmo, na torre principal atoparon o tellado incompleto, xa que non alcanzaba a cubri-las paredes, polo que mandan que se faga de tal xeito que as augas vertan fora. Finalmente, "quitar las çarças e linpiar algunas cosas", traballo que taxaron nun ducado.

O 19 de outubro do 1535, na visita ás fortalezas da mitra compostelá, non se atopou en Rodeiro de que facer taxación, incluso as testemuñas Xil de Bonxe e Xurxo González dixeron "que la dicha casa no rresçibiera ningun daño en tienpo del señor cardenal antes la veyan estar mejor rreparada e asy lo declararon" 20.

$\mathrm{Na}$ seguinte visita, en 10 de xullo do 1544, en presencia do escribán, as testemuñas, e de Gregorio de Seoane e Xoán Pérez, canteiros e alarifes, compareceron e xuraron Vasco de Puga, alcalde e meiriño da fortaleza de Rodeiro, e Xil de Bonxe, tenente de xuíz de Rodeiro. A situación do edificio era o mesmo, declarando o dito Vasco de Puga "que save vien que en tienpo del dicho don Pedro Sarmiento siendo tal arçobispo ningund dapno se hizo en la dicha fortaleza de rrodero porque este testigo la vive y haze bevir [...] e como la bive e haze bevir sienpre a rreparado e rrepara en ella y esto hes la verdad". O tenente de xuíz vive xunto á fortaleza, que non ten danos porque Vasco de Puga "la haze bevir la haze rreparar y adereçar" 21 .

\footnotetext{
${ }^{17}$ Decl. de Xácome de Marinaos, RODRÍGUEZ, Op. cit., T. I, páx. 171.

${ }^{18}$ Decl. de Estevo Fariña.

${ }^{19}$ RODRÍGUEZ, Op. cit., Tomo II, páx. 502-505.

${ }^{20}$ C. OLIVERA SERRANO, El ocaso de las fortalezas compostelanas. Visitas y tasaciones (15351547). Instituto de Estudios Gallegos "Padre Sarmiento", Santiago de Compostela, 200, páx. 74.

${ }^{21}$ OLIVERA, Op. cit., páxs. 105-106.
} 
A última visita, do 3 de outubro do 1547 ten como testemuñas a Fernando Calviño e Alonso de Rodeiro, veciños do "corral" da fortaleza de Rodeiro, que depoñen "que syenpre desde veynte años a esta parte poco mas o menos tienpo an visto de la misma manera que agora esta". Ademais, indican "que en el tienpo que fue perlado e arçobispo del estado e arçobispado de Santiago el rreverendisimo señor don Gaspar de Avalos de buena memoria hasta que se fallesçio desta presente vida no an visto ni saben de otros daños que aya avido ni ayan en la dicha fortaleza de Rodero sino unos dos pasales que faltan en la escalera de la torre que heran de madero e algunas tejas e tablas de lo alto e no saben de otra cosa", danos que taxan os alarifes en douscentos marabedís ${ }^{22}$.

No tocante ó equipo interior, no 1567 posuía de armamento "dos cañones de dos arcabuces viejos, sin las caxas; una ballesta muy buena con sus gafas ${ }^{23}$; media docena de tiros; cuatro lanzas". Para cumprir a súa función de prisión "dos cadenas muy buenas, una grande y otra más pequeña, con sus candados; seis farropeas ${ }^{24}$ con sus focales; unos grillos" 25 .

Un documento do ano $1576^{26}$ ofrécenos datos sobre casas e herdades anexas e pertencentes á fortaleza de Rodeiro. Entre elas, unha casa onde está a corte dos cabalos "que está junto del pasadizo de la dicha fortaleza, con su cámara de fuera". Supoñemos que se trata dos restos do antigo pazo do Arcebispo, cerca da barbacá.

Tamén a casa onde acostumaba vivir Lopo Xil, en que vive o escribán "desde una cámara que tiene abajo", e outra casa "que está cabe dela", que fixo o dito Lopo Xil. Así mesmo, cítase unha casa na que vivía Margarida de Rodero, na que acostumaban facer Audiencia.

No tocante á propia fortaleza, a finais deste século XVI notábase un profundo deterioro, apreciable nunha descrición da mesma levada a cabo no ano 1596 con motivo dun apeo dos bens do arcebispado de Santiago na xurisdicción de Rodeiro $^{27}$.

Una torre gruesa con nueve pies de ancho de parede de grano y de diez varas en alto (...) por lo alto está desmantelada y sin almenas, caída por dos partes (...) la cual no tenía cubierta de texado ni de otra cosa, y así se llueve todo y paresce que tuvo tres suelos y solo está agora un suelo, que es el primero de la entrada de la puerta de la dicha torre, el cual suelo es de maderos y de allí abajo hay un sótano, que por este

\footnotetext{
22 OLIVERA, Op. cit., páx. 135.

${ }^{23}$ Instrumento para monta-la bésta, que tensa a corda ata que esta queda enganchada na noz.

24 Vocábulo antigo para designa-lo grillón, os ferros para o amarre dos presos.

25 AHUS, mitra 44.

26 AHUS, mitra 37.

27 AHUS, mitra 39.
} 
suelo paresce se entraba por una trapa [sic]. Esta torre está en medio y a la redonda desta dicha torre tiene una muralla bien formada de almenas y tiene como cinco pies de ancho, todo de piedra de grano y fuerte, y este castillo se entra por una puerta de palo y fuera desta puerta estaba un andén como de seis o siete pies de ancho que torno el cual está debajo de contramuralla de piedra de grano y de pizarra, de como dos estados poco más o menos por toda la redonda, hestá casi raso por algunas partes con el andén, sin parapeto a la redonda mucha parte dello (...). Esta fortaleza está sita en una pena viva fortísima, de donde se entiende ser muy fuerte y no poderse minar de ninguna manera, entrase por una puerta que está al mediodía, la cual no tiene puertas de hierro ni de madera, ni la dicha torre tampoco. Está esta primera puerta de contramuralla como un estado del quelo del foso, el cual lo tiene todo a la redonda, y la dicha puente es de madera y está toda desbaratada y desguarnecida y sobre la puerta de la fortaleza hay una torreciela de altura de seis braças en alto, poco más o menos, almenada, que de dentro no tiene suelo ninguno, ni ventana, sino dos puertas que salen a la una puerta de la muralla hacia el medio y la otra a la parte del vendaval, y el estado que tiene esta dicha torreciela está desbaratado de suerte que se llueve en el (...).

(...) Encima de la primera puerta, en la muralla principal, en la segunda muralla que arrima con la torre está un escudo de armas de don Alonso de fonseca, Arzobispo que fue de Santiago.

$Y$ encima de la puerta de la torre grande está un escudo de armas que tiene seis ruedas de carro de carreta, que dicen son las armas del linaje de Rodeiro ${ }^{28}$.

\section{II.1.4. O século XVII}

A robustez da construcción medieval fixo que, pese ó abandono que sufriu, resistise os embates do tempo, manténdose practicamente coa mesma estructura ata que desapareceu.

O 24 de marzo do 1600 Miguel e Bartolomé Calviño reciben en foro o lugar e torre de Rodeiro, que lles fixo don Alonso de Puga, que o leva por foro do arcebispo de Santiago, en renda de nove fanegas de centeo e sete galiñas, así como outras dez fanegas que deberán aboar á Dignidade Arcebispal ${ }^{29}$.

Coñecemos un presuposto para o seu arranxo do 15 de maio do $1617^{30}$. comparece como testemuña Gregorio López Varela e Ulloa, que declara sobre a utilidade da fortaleza "viviendo siempre en ella los jueces del juzgado de Camba y

\footnotetext{
${ }^{28}$ Estas labras deberon desaparecer coa destrucción da fortaleza, o que constitúe unha auténtica perda para a heráldica dezá, principalmente no caso da pedra armeira dos Rodeiro, que sería unha das máis antigas da zona e única desta liñaxe que se conservaría nela. Das armas dos Rodeiro, as seis rodas de carro, descenden con seguridade as dos Camba, que diminúen o número dos mobles a dúas ou catro rodas.

${ }^{29}$ AHUS, Clero, Mitra 42.

${ }^{30}$ Arquivo Histórico Diocesano de Santiago, Fondo Xeral, serie Visitas Pastorais, atd. 2, ff. 241v243r. Documento facilitado polo investigador cuntiense e amigo don Héitor Picallo Fuentes.
} 
Rodeiro, y teniendo los presos en ella y aprovichándose a los demás ministerios que servía y podía servir". O dito Gregorio afirma que estaba sen pisos e que o arcebispo Xoán de San Clemente "la mandó cubrir de madera y teja a García de Pardiñas, su juez, abía diez y siete o diez y ocho años, poco más o menos [...] y sabe el testigo la cubrió y tejó Pedro Gómez de Seren, oficial de carpintería, y tejola y estubo cubierta asta que abrá cossa de cuatro años que se hundió la madera, y teja, y cayó en el suelo y si tiene alguna al de presente no save este testigo si servirá". No que toca ás outras construccións "ansimismo save este testigo y vio quel cuarto de la casa donde vive el juez lo redificó el dicho García de Pardiña, criado del señor don Joan de San Clemente, siendo su juez, y por su horden y mandado según y de la manera que al presente está". Así mesmo "oio este testigo que la torre del castillete se cayó después que fallesció el señor Maximiliano de Austria, que estava el techo hecho y cayó en tiempo del señor don Joan Beltrán de Guebara, con tormenta de ayre, y ansimismo save el testigo que en tiempo de Joan de Muros, juez que a sido por el señor Maximiliano de Austria, se quemó la casa de la cárcel, que está junto a la fortaleça, la cual estava cubierta de paja y madera tosca, y de poco balor, que se iba cayendo y se caia sino se quemara, y es necesario para la cárcel por no hacer otra". O mesmo declaran Gregorio Calviño, Xoán de Eiriz e Bartolome Calviño.

No mesmo documento se inclúe a taxación dos reparos levada a cabo o 16 de maio do mesmo ano 1617 por Francisco González de Araúxo e Gaspar de Arce, mestres de cantería, e Alonso de Veade e Xoán Valera, mestres de carpintería, e declararon, despois de examinada a fortaleza de Rodeiro a necesidade das seguintes reparacións:

- De cantería, "lebantar el petril y almenas de la dicha fortaleça, y fixar y apretar las demás que están lebantadas". Importe, 770 reais.

- Carpintería: os mestres "allavan la dicha torre que havía sido cubierta de madera y teja, y muy vien se hechaba de ver porque aún tenía arriba madera y teja, y demostrava haber estado reparado". Para reparalo de novo, 500 reais, entrando nesta cantidade "madera, clavos y trabajos de oficiales y todo lo demás necesario para ello".

- Na torre de entrada. "Dijeron que para la torre que está sobre la puerta de entrada de la dicha fortaleça, que llaman castillete, hera necesario cubrirlla de madera y teja, como demuestra aber estado". Custo, 300 reais.

- Cortes dos cabalos: Nelas será "necesario hechar dos vigas de roble". Custo, 33 reais, as vigas e oficiais.

- Vara da torre: Declararon "que se pueden hacer tres suelos, los cuales se demuestra haver estado hechos antes de aora". Para facelos serían 
necesarios vintecatro vigones a catro reais cada un e duascentas táboas, cun custo de douscentos vinte reais, ademais de cravos e oficiais, que importan cento cincuenta reais.

- A ponte de entrada da dita fortaleza necesita "tres bigones de roble y tablas", o que monta corenta e catro reais.

- A casa preto da fortaleza que servía de cárcere "que está quemada", para reedificala é necesario "deshacer un pedaço de pared que esta al setentrional que está para caerse y rachar, e igualar en una pared que parte la casa por medio", o que custará sesenta e catro reais. No que toca á carpintería, os mestres declararon "que para cubrirse con sus vigas, y madera y paja, como está de antes, y puertas y ventanas" serían precisos 250 reais. E "para el servicio de la dicha casa ser necesario un suelo sobre vigas de la pared que parece por medio de la casa acia la torre, aunque de antes no le havía" cun custo 150 reais.

Noutro documento do 29 de agosto do 1636 indícase que estaba preto dela " $\mathrm{el}$ río y dehesa del Hospital y heredades del Campo de la Feria, que se suelen labrar" 31 .

\section{II.1.5. Século XVIII}

No ano 1783 faise un recoñecemento da fortaleza de Rodeiro ${ }^{32}$, levándose a cabo indagación do seu estado, xa que, segundo se expresa no documento "la Iglesia de Santiago tiene en San Vicente de Rodeiro una Fortaleza que llaman vulgarmente Torre de Camba, o Castillo, que es más vulgar". Escolléronse testemuñas de máis de sesenta anos, que declararon a existencia de "una torre y fortaleza de crecida elevación y altura, con un castillete por la parte de poniente", así mesmo, todos a lembran sempre así, sen piso nin teito.

Tamén se require a declaración dun perito da que se extrae a seguinte descrición:

"Construída con pedra de cantería labrada a perfección, cuia pared tiene de ancho doce cuartas y de alto no pudo saber lo que componía por su crecida elevación, la que de abajo arriba y hasta lo último, se advierte y encuentra perfecta y sin alguna lesión, escalo o rohína, con una sola puerta por la parte de Poniente, el que se encuentra fabricado con la misma piedra de dicha Torre, entero y sin falta alguna, siendo sus remates unas almenas que le circundan, sin que tampoco pudiese medirlo por su maior altura, ni tenga escalo ni otra deterioración. En igual manera reconoció un foso y contrafoso que circundan la citada torre y fortaleza y se advierten

\footnotetext{
${ }^{31}$ AHUS, Clero, Mitra 42.

${ }^{32}$ AHUS, Clero, Mitra 44.
} 
caídos y arruinados por algunas situaciones, lo que sin duda pudo acaecer de ser muy antigua su fábrica y la piedra muy mala. Dicha Torre y Fortaleza no tiene techo, ni piso alguno, y lo mismo sucede con el castillo".

\section{II.1.6. O momento actual}

Desde a descrición citada de finais do século XVIII, non coñecemos a evolución dos danos que foi sufrindo a antiga fortaleza de Rodeiro co decorrer dos tempos. A súa desaparición data de finais do século XIX, conservándose restos tamén a comezos do XX e incluso ata a época actual, diseminados por varias construccións dos arredores.

Entre estes restos, varios signos lapidarios en sillares dunha construcción cerca do edificio do concello, que ocupou, incluso esteticamente, a situación da desaparecida torre de homenaxe. Así mesmo consérvanse, á beira do edificio municipal, varios metros dunha muralla de máis dun metro de ancho, vestixio dunha das primitivas fortificacións do recinto murado, composta de dúas caras, a exterior de sillares de cantería e a interior de pedra de peor calidade, e entre ámbalas dúas recheo de terra de pedras. E non só iso, senón que mesmo o río parece que segue a antiga "caba" ou foso, polo que desviaban o curso de auga se era preciso noutros tempos.

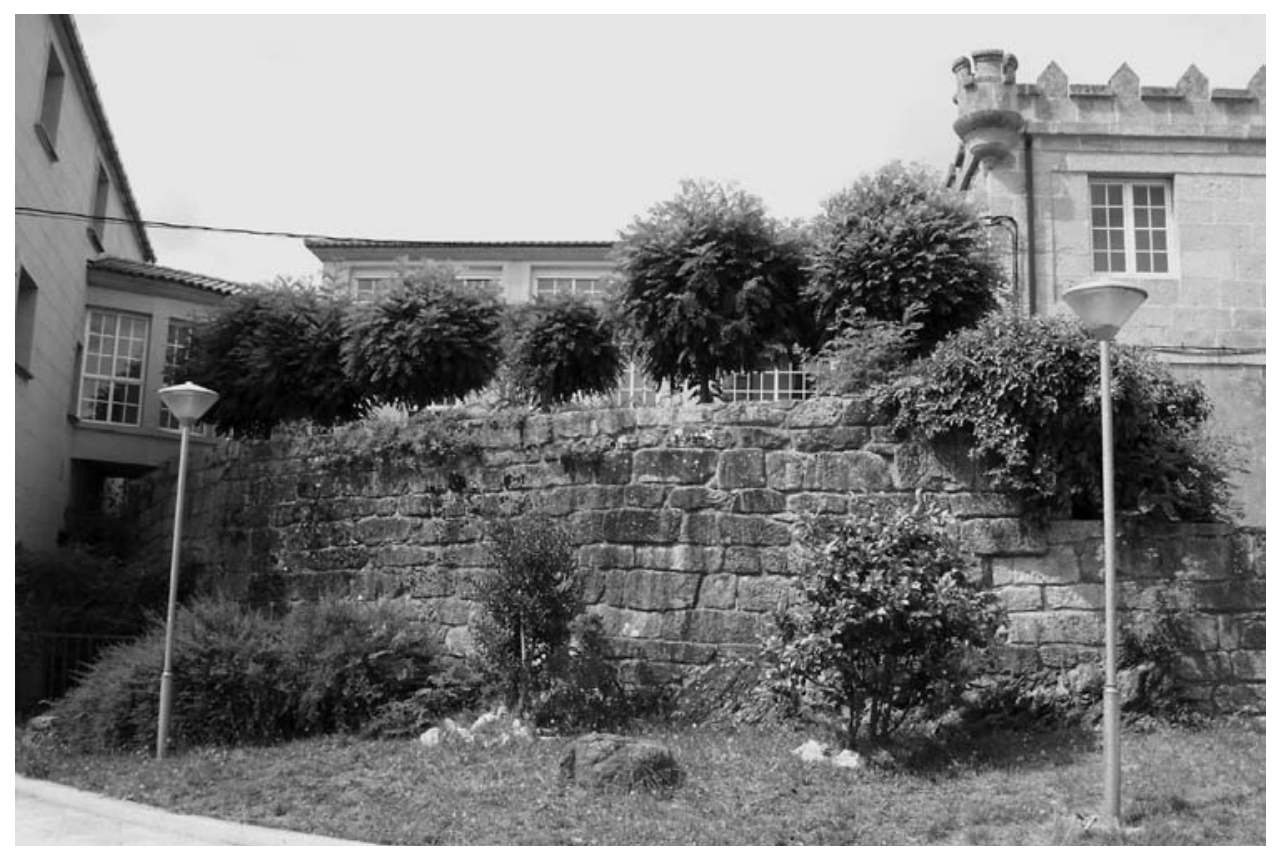

Figura 6: Restos da antiga muralla da fortaleza que aínda rodean o concello. 
Vestixios todos eles dunha pequena fortaleza que noutros tempos foi centro da xurisdicción e referente dunha terra que aínda hoxe lembra a perda irreparable que supuxo para o seu patrimonio e identidade a desaparición dunha construcción emblemática.

\section{II.2. Fortaleza de Seoane de Camba}

O outro polo de poder nas terras do actual concello de Rodeiro foi a fortaleza de Seoane de Camba. As súas orixes quizais se atopen, como as da anterior, ligadas ós Rodeiro. Non fagamos caso das antigas lendas, sen fundamento algún, que fai ós Camba remotos descendentes dun Lupo Cambero de Candad, señor do castelo de Castro Candad nos tempos da Reconquista, do capitán romano Gelión Cambero e do cónsul Gelión Cambero Cándido ${ }^{33}$. É moito máis razoable a suposición, apoiada nas respectivas armerías, do parentesco máis ou menos próximo entre as liñaxes dos Rodeiro e dos Camba.

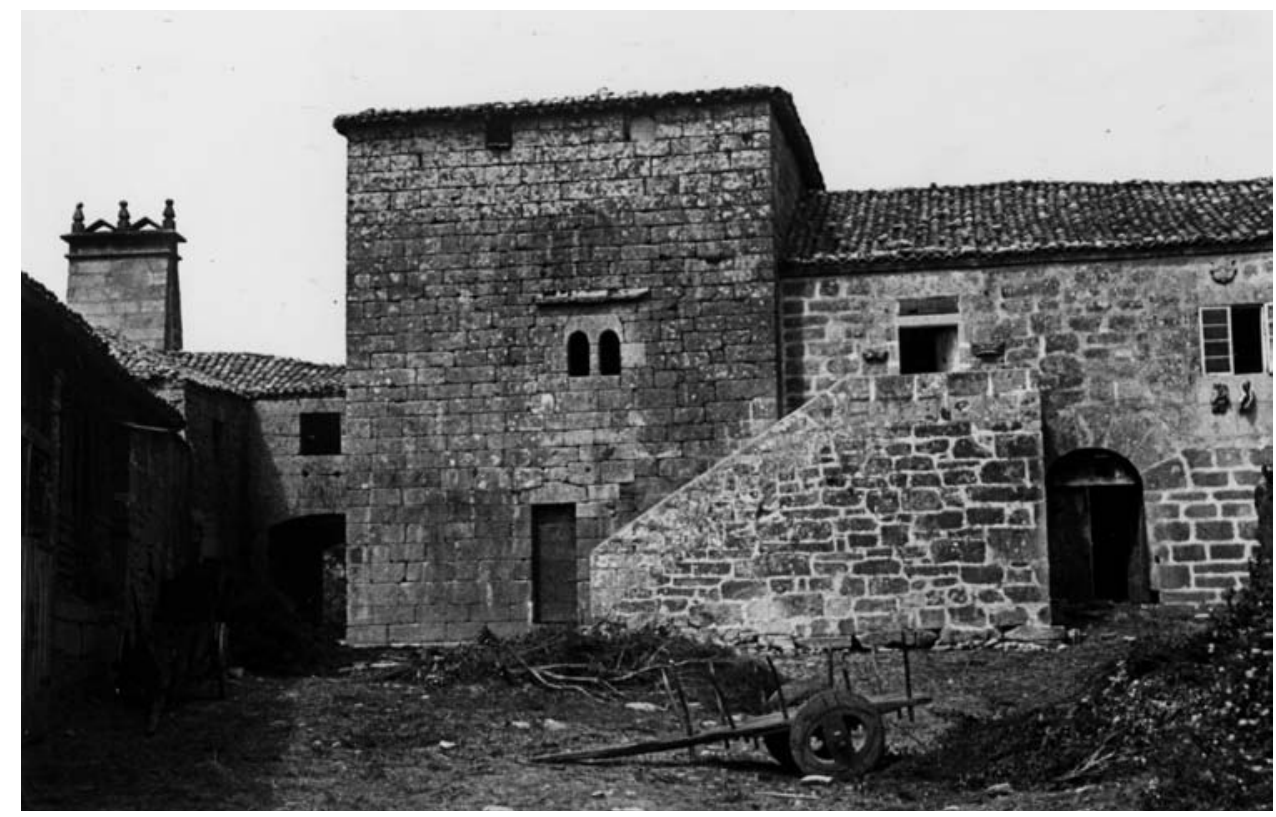

Figura 7: Imaxe de Camba nos anos 40 do pasado século

(Museo de Pontevedra. Fondo Durán-Loriga).

${ }_{33}$ M. VÁZQUEZ SEIJAS, Fortalezas de Lugo y su provincia (notas arqueológicas, históricas y genealógicas). 6 vol. Deputación Provincial de Lugo, Lugo, 1997. Tomo I, páx. 93. 
Constitúe a fortaleza de Seoane de Camba un claro expoñente da evolución desde á casa forte medieval ata as estructuras pacegas propias dos séculos XVII e XVIII. Da súa fábrica primitiva conserva a forte torre de homenaxe do antigo castelo, de tres plantas, con muros duns dous metros de grosor e numerosas marcas de canteiro nos seus sillares. Mantense aínda unha fiestra xeminada na fachada principal, correspondendo ó interior á sala onde se atopa o antigo arquivo de parede de cantería.

Nos primeiros anos do XVII érguese o grande edificio anexo á torre, con escaleira de acceso e dúas labras coas armas dos Camba que flanquean a porta de entrada. Destaca tamén a "casa de cociña" con grande cheminea que constitúe un fermoso conxunto coa de salón ${ }^{34}$.

En todo o conxunto, e incluso na igrexa hoxe parroquial, e que antigamente debía estar anexa á casa, se repite a emblemática dos Camba, evolución certa daquelas seis rodas de carro dos Rodeiro, que figuraban, como xa vimos, na fortaleza de Rodeiro. Algunha das representacións máis antigas destas armerías dos Camba figuran no mosteiro de Ferreira de Pallares, na capela dos señores de Taboada, do século $\mathrm{XV}^{35}$.

No tocante á súa historia, como xa dixemos, débense buscar posiblemente as súas orixes na persoa de Vasco Fernández de Rodeiro, señor desta terra. Sobriña de Vasco foi Maior Vázquez de Rodeiro, casada con Alonso Suárez de Deza, Adiantado Maior da Galiza, asasinado polo arcebispo Berenguel de Landoira na Rocha no 1320, e destes dous foi neto Álvaro de Camba e Taboada, razón probable pola que pasou a mans desta liñaxe a fortaleza.

A súa descendencia é ben coñecida. Destacar tan só a figura de Fernando de Camba, capitán na guerra de Granada cos Reis Católicos, do que, segundo a tradición, se conserva a sepultura, posiblemente reempregada, no atrio da igrexa parroquial. Tanto el como o seu irmán, Lope de Taboada figuran nas crónicas da época sobre todo en relación coas loitas entre "Pedro Madruga" e o arcebispo Alonso de Fonseca ${ }^{36}$.

\footnotetext{
${ }^{34}$ Un completo estudio da arquitectura desta construcción en C. GÓMEZ BUXÁN e F. RUBIA ALEJOS, Pazos y moradas hidalgas de Deza. Deputación Provincial de Pontevedra, Pontevedra, 2005, páxs. 253-262.

${ }^{35}$ Nunha das labras dos monumentos funerarios que alí se atopan aparecen as rodas de carro completas, xunto coas partes destas alusivas á liñaxe, as "cambas". C. GÓMEZ BUXÁN, "As armas dos Taboada. Aproximación a unha peculiaridade heráldica dezá". Cuadernos de Estudios Gallegos, Tomo LII, Fascículo 118, páxs. 389-426. Santiago de Compostela, Instituto de Estudios Gallegos "Padre Sarmiento", 2005.

36 Véxanse, por exemplo, os relatos de Vasco de Aponte, onde figuran reflectidos en variadas ocasións. V. DE APONTE, Recuento de las Casas antiguas del Reino de Galicia, introducción y edic. crítica con notas [equipo de investigación "Galicia hasta 1500", integrado por M. Díaz y Díaz...], Santiago de Compostela, 1986.
} 


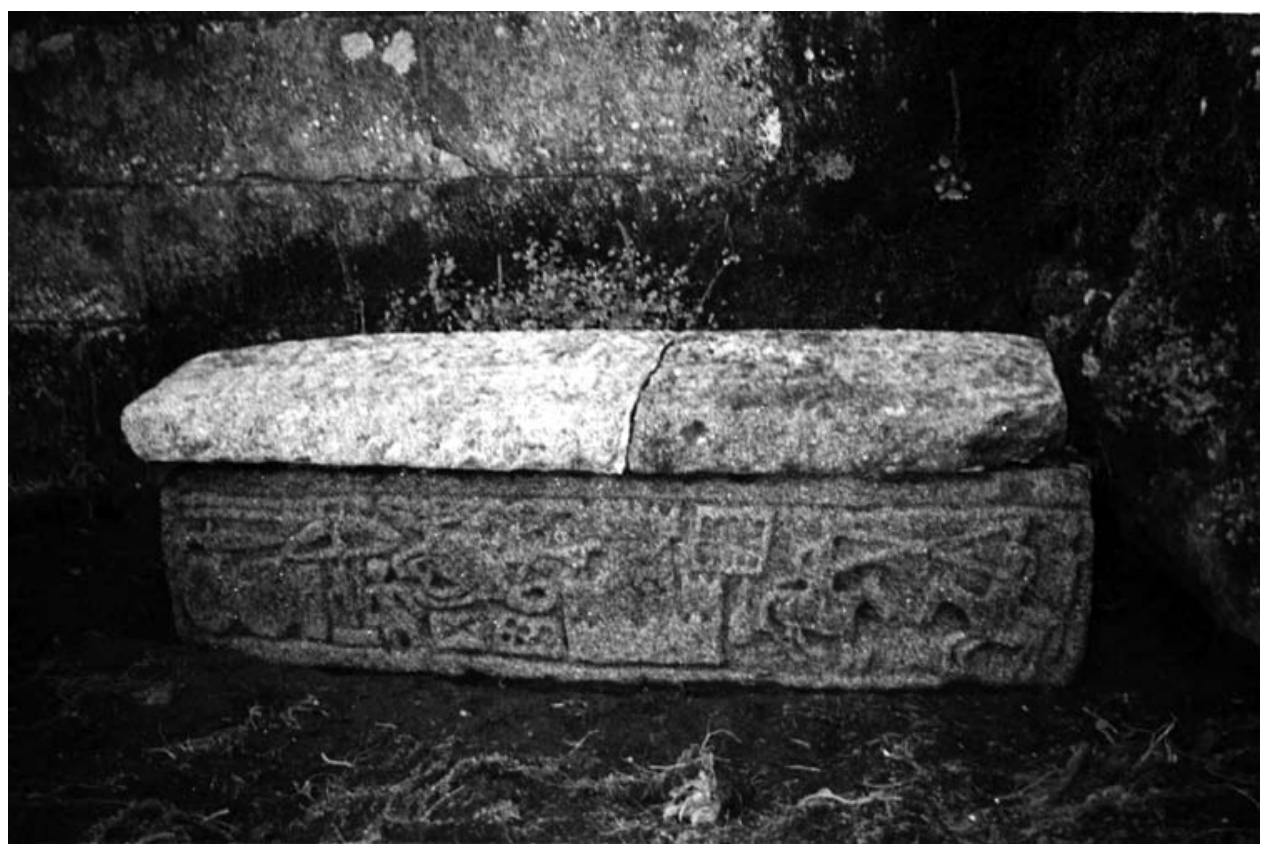

Figura 8: O sartego de Fernando de Camba, á intemperie no adro da igrexa parroquial.

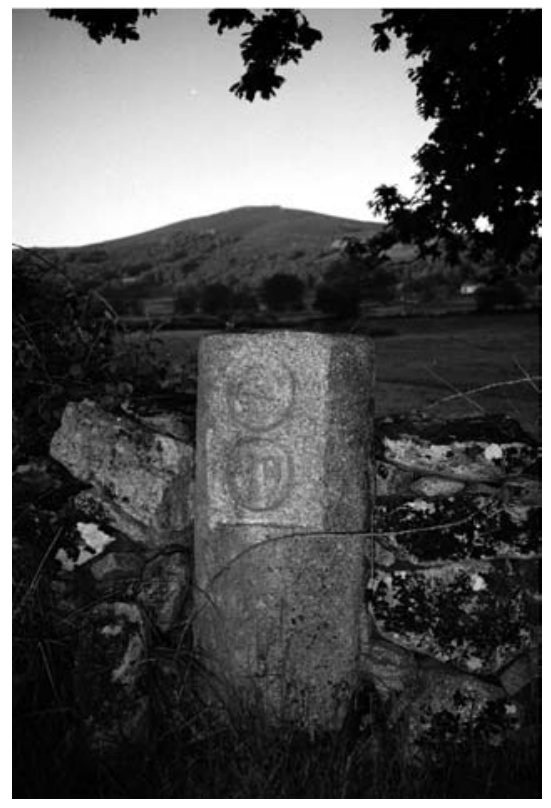

Figura 9: Marco coas armas dos Camba.

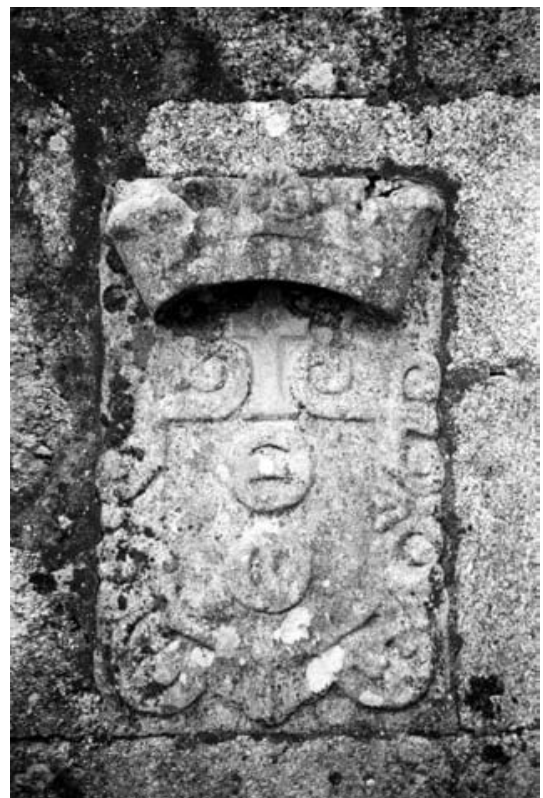

Figura 10: Unha pedra armeira do pazo. 
O pretendido sartego de Fernando de Camba constitúe unha mostra de grande interese na escultura funeraria de Deza e que merece un estudio detallado. No seu fronte, curiosas representacións de elementos de carácter militar, incluídos dous cabaleiros cruzando as súas lanzas nunha especie de torneo ou batalla (as puntas das lanzas van cara á cabeza dos contendentes).

O 5 de decembro do 1548 Pedro de Camba Villamarín, o Vello, fundou o vínculo e morgado da fortaleza de Camba, que seguiu en posesión dos seus descendentes ata que don Melchor de Camba Ozores finou no 1774 sen descendencia lexítima, co que as propiedades pasaron á descendencia do seu parente don Fernando de Miranda Vivero e Camba, da casa de Lagariños, na que, a mediados do século XIX recaeu o título condal de Villapún.

No 1935 os propietarios venderon os bens a don Manuel Pérez Fafián, antepasado dos actuais donos ${ }^{37}$.

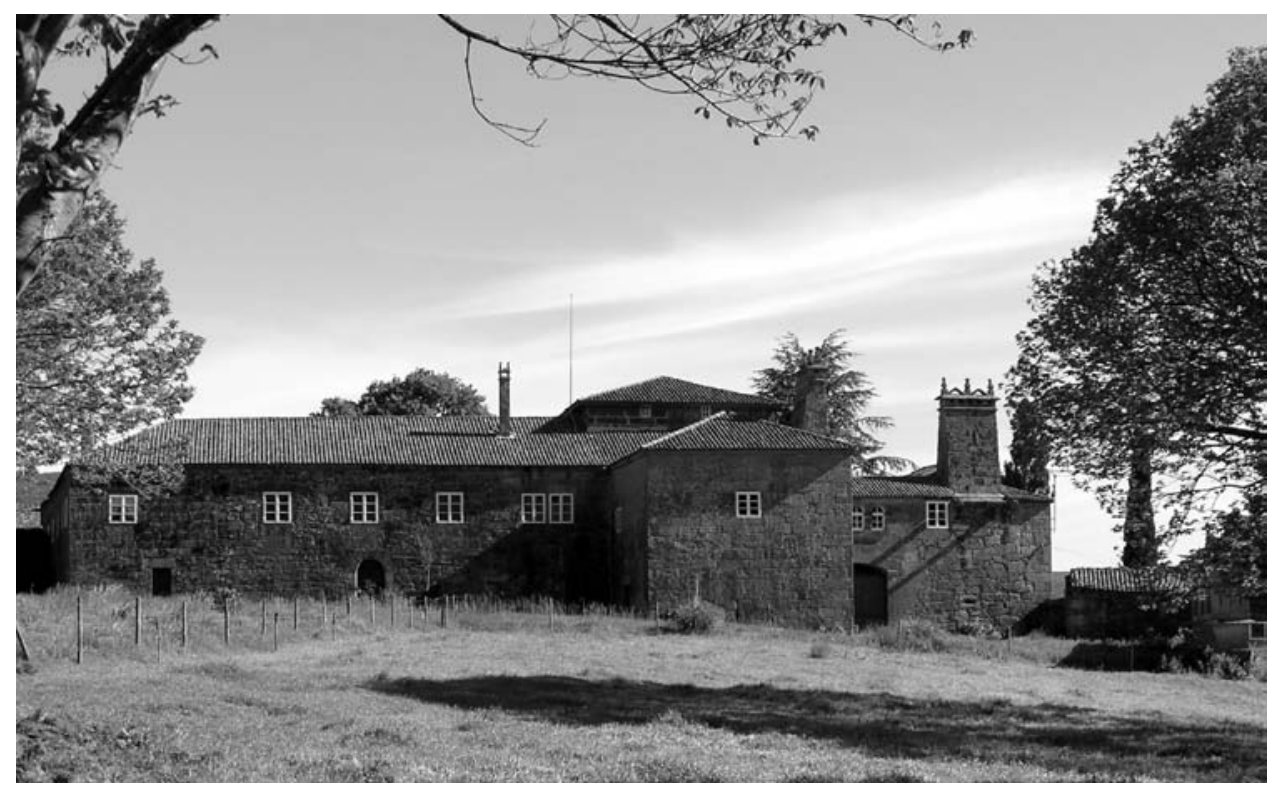

Figura 11: Parte traseira do fermoso pazo-fortaleza de Camba.

${ }^{37}$ Estes son autores de un magnífico estudio monográfico sobre a antiga casa de Camba. Véxase L. PÉREZ FERNÁNDEZ e L. F. PÉREZ MÉNDEZ, Historia de la Casa-fortaleza de Camba. Deputación Provincial de Pontevedra, Pontevedra, 1998. Debido á existencia destas publicacións cremos innecesaria a achega de máis informacións sobre esta fortaleza. 


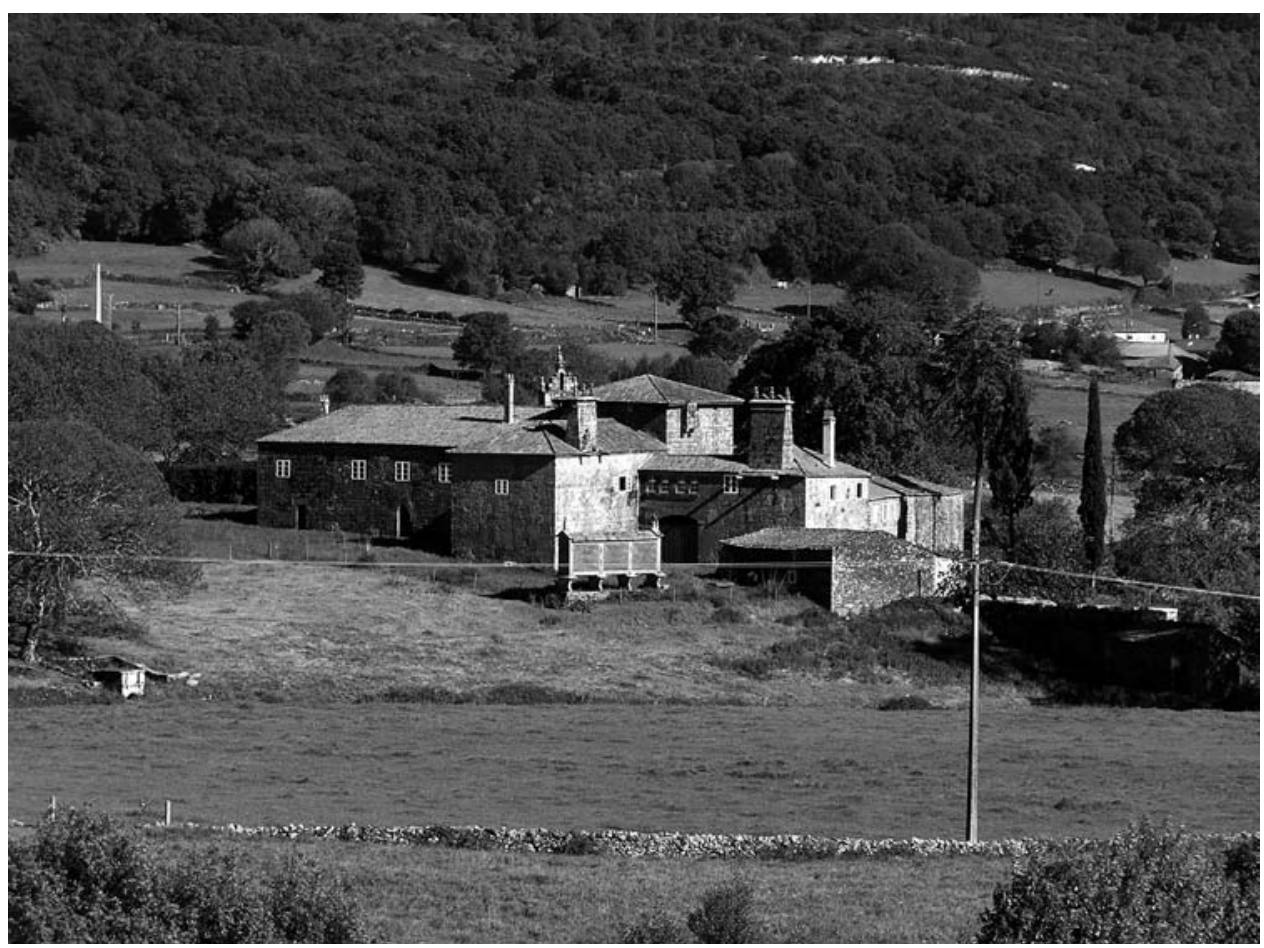

Figura 12: Impresionante imaxe do conxunto pacego desde a lonxanía.

\section{AS TORRES}

\section{III.1. Torre de Outeiro}

Na parroquia de Santiago de Fafián, atopamos outro exemplo do que foron as construccións representativas do poder nunha xurisdicción nos séculos que van ata o XVI. Trátase da chamada Tulla de Outeiro, nome que quizais recibiu pola súa condición de centro recadador de rendas.

Consérvase, mantendo aínda o seu porte, a torre, duns 10 por 8 metros, de tres plantas, sen teito nin piso. Os muros, como corresponde a una edificación do XVI, non ten a característica fortaleza das construccións defensivas de séculos anteriores. De diversos grosores, oscila entre os $120 \mathrm{~cm}$ do baixo ata os $80 \mathrm{~cm}$ de grosor no terceiro andar. A porta, como era habitual, ó nivel da segunda planta, accedéndose a ela por unha rampla. 


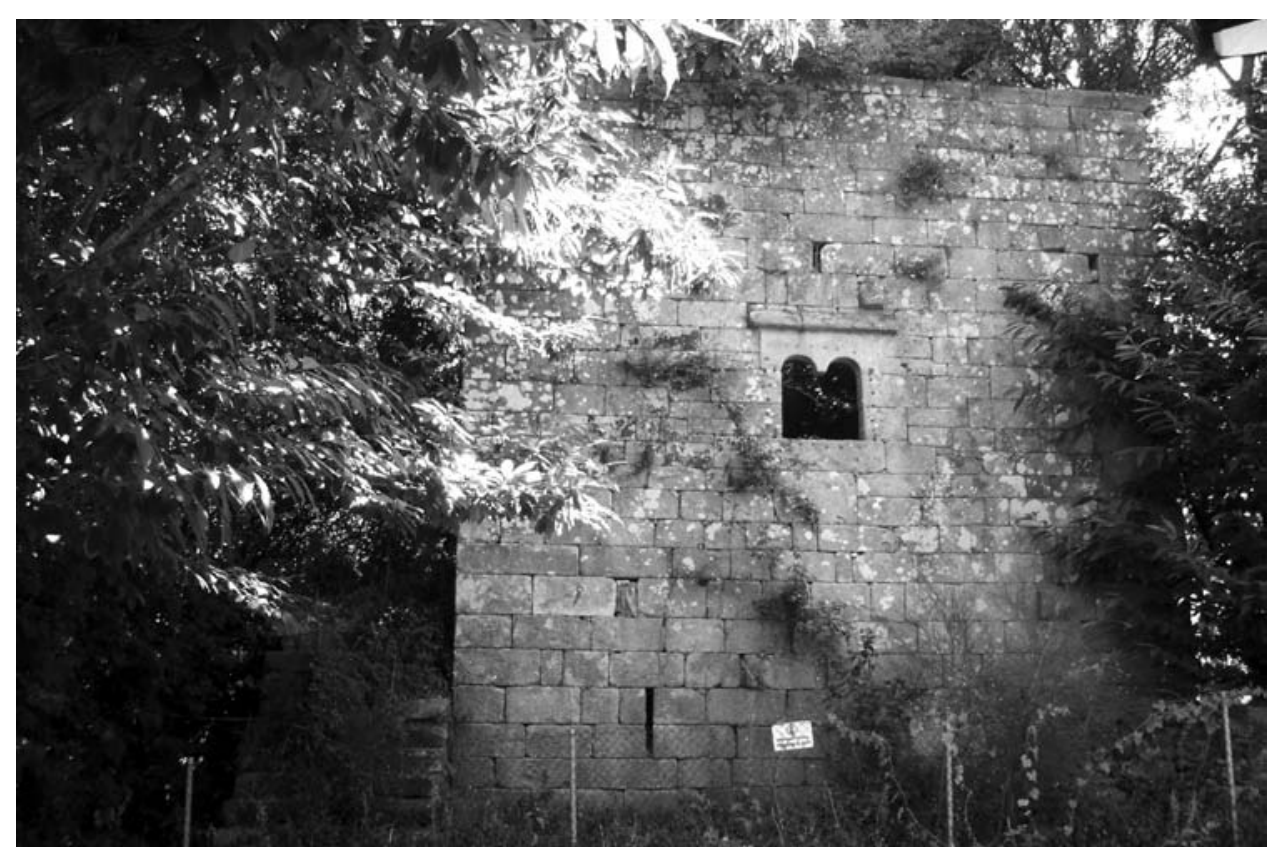

Figura 13: Unha imaxe da fachada da torre de Outeiro, coa escaleira de acceso ó segundo andar.

Dos elementos que noutro tempo formaron parte da súa estructura permanecen fiestras con arcos xeminados, ó interior cos típicos "parladoiros", así como unha garita que tivo a función de retrete, a nivel da primeira planta ${ }^{38}$.

O entorno da torre é un magnífico exemplo de núcleo rural, que sería interesante protexer. Á súa beira, enormes castaños centenarios e típicas construccións, incluído un fermoso pombal recentemente restaurado ${ }^{39}$.

A historia coñecida da torre de Outeiro comeza cos Lemos, liñaxe de avoengo nas terras de Lugo. De Lope Sánchez de Ulloa e Lemos, señor da casa principal dos Lemos, e da súa dona Isabel González Noguerol, herdeira da fortaleza de Amarante, naceu, entre outros fillos, o primeiro habitante que coñezamos desta torre, que foi Rodrigo Fernández Noguerol ${ }^{40}$.

A el o arcebispo de Santiago, Alonso de Fonseca, lle outorgara "por los días de su vida" o xulgado da terra de Camba, habitando no lugar de "Otero de

${ }^{38}$ E non coa función, como se afirma en algunha outra publicación que non citamos, para bota-lo gran nos carros.

${ }^{39}$ Un primeiro estudio da arquitectura e historia da Torre de Outeiro en GÓMEZ e RUBIA, $O p$. cit., páxs. 275-280.

${ }^{40}$ Colle os apelidos da súa ascendencia materna. 
Camba". Renunciou ó cargo, e o 5 de febreiro do 1543 prega ó arcebispo que lle faga mercé do dito Xulgado ó seu irmán, o licenciado Alonso López de Lemos e Ulloa $^{41}$.

Este ocupou o cargo durante varios anos e, do seu matrimonio con Inés de Castro veulle ós seus descendentes a posesión da Fortaleza de Villar (Santiago de Esperante - Taboada), xa que esta dona era filla de Fernando de $\mathrm{Camba}^{42}$ e de Maior de Ulloa, donos da mesma. Deles foi primoxénito Diego de Lemos e Camba, "dueño de la casa, Fortaleza y mayorazgo de Villar"43.

Por esta descendencia pasou primeiramente á casa de Fefiñáns, en Cambados, e logo, polo enlace de dona Ana de Lemos co conde da Vega de Sella ${ }^{44}$. No 1753 don Pedro Duque de Estrada, conde de la Vega de Sella e señor de Villar "su casa fortaleza y jurisdicciones", veciño da vila de Madrid, posuía no lugar de Outeiro de Camba unha "casa de tulla"45.

\section{III.2. Torre de Senra}

Na freguesía de San Paio de Senra houbo unha torre, edificada a comezos do século XVI ou incluso antes, que tivo unha certa relevancia, non polas posesións dos propietarios, senón pola probada fidalguía das súas orixes.

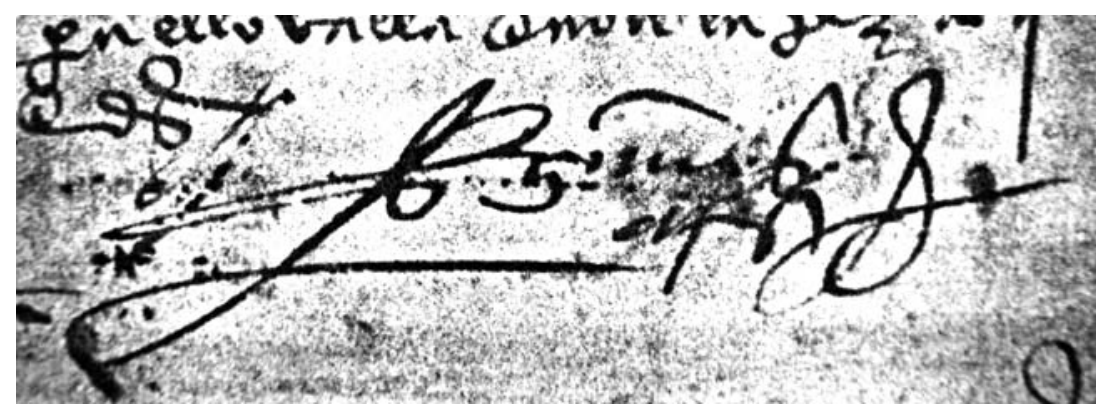

Figura 14: Sinatura de Gómez Ares Mosquera.

${ }^{41}$ AHUS, Clero, Mitra 44.

42 Fillo de Juan Rodríguez, señor da fortaleza de Seoane de Camba.

${ }^{43}$ AHUS, protocolos, Cristóbal Gundín, 1596.

44 Título concedido por Felipe IV o 31 de decembro do 1647 a prol de don Fernán Duque de Estrada. A. A. DE CADENAS Y LÓPEZ e V. DE CADENAS Y VICENT, Elenco de Grandezas y Títulos Nobiliarios Españoles, vigésimo quinta ed. Madrid, Ediciones de la Revista Hidalguía, 1992, páx. 947.

${ }^{45}$ AHUS, Clero, Mitra 43. 
O comezo parte do foro que fixo o arcebispo de Santiago de Compostela no 1537 a prol de Gómez Ares Mosquera e de Beatriz Oxea, a súa muller, veciños de terra de Camba, dos lugares de Senra e Cima de Vila, en San Paio de Senra, polas súas vidas e dúas voces, en renda anual de once fanegas e media de centeo e un carneiro ${ }^{46}$, foro que foi aprobado de novo no 1554 "con tal de que en el se entienda comprendido el de Vila de Cima"47. Este mesmo Gómez Ares Mosquera semella ser o que figura citado como meiriño da Fortaleza de Rodeiro no preito Tábera-Fonseca. De Gómez e Beatriz coñecemos dous fillos: Leonor e Lope Suárez Mosquera.

Este último naceu sobre $1546^{48}$ e vivía aínda o 2 de novembro do $1596^{49}$, finando posiblemente a finais dese mesmo ano, pois nun apeo aparece a súa muller como dona dos bens. No 1576 veciño de San Paio de Senra, onde tiña "una casa de fuego y una torre junto a ella y tres cortes y otra casa para servicio" 50 .

Casou Lope con Antonia Vázquez da Senra (ou da Cervela), e non tiveron sucesión, polo que o 2 de novembro do 1596 ante o escribán Juan García fixeron doazón a prol da súa sobriña Gerónima López da metade do lugar de San Paio de Senra, en razón de dote para o seu casamento ${ }^{51}$.

A outra filla de Gómez Ares Mosquera, Leonor Gómez, casou antes do 1576 con Mendo da Cervela ${ }^{52}$, posiblemente da liñaxe dos posuidores de Vilar do Fondo, en Riobó. Nun apeo do arcebispado de Santiago figura o matrimonio como propietario en San Paio da Senra, lugar da súa residencia, "una casa y una torre de habitación con tres casas".

Destes últimos naceu Jerónima López, posuidora dunha metade do lugar de San Paio da Senra polos seus pais, mentres que a outra metade lle foi dotada polos seus tíos Lope Suárez Mosquera e Antonia Vázquez para que casase con Juan Rodríguez Varela e Ulloa, descendente do pazo de Trasulfe, en Santiago de Fafián ${ }^{53}$.

46 AHUS, Clero, Mitra 42.

${ }^{47}$ Idem.

${ }^{48}$ AHUS, Clero, Mitra 37.

${ }^{49}$ AHUS, Clero, Mitra 42.

${ }^{50}$ AHUS, Clero, Mitra 37.

51 AHUS, Clero, Mitra 42.

52 Posiblemente o matrimonio foi dos chamados "a troco", xa que este Mendo debía ser irmán da citada Antonia Vázquez da Cervela. Era moi habitual que se efectuasen estes casamentos nos que as a lexítima dos noivos quedaba na casa, co que se evitaba a fragmentación das herdanzas.

${ }^{53}$ Fillo de Pedro López Varela de Dubra e da súa segunda muller Sancha Álvarez de Baamonde, fundadores como veremos do vínculo do pazo de Trasulfe. 
O 29 de marzo do 1665 o arcebispo de Santiago volveu facer novo foro do lugar de San Paio da Senra a prol de María Mosquera, viúva de Amaro Vázquez, veciña da freguesía, bisneta do dito Gómez Ares Mosquera, por vida de tres reis, en renda anual de once fanegas e media de centeo e un año.

No século XVIII figuran dúas informacións relativas a unha torre na freguesía, procedentes ámbalas dúas dun apeo levado a cabo no 1760 pola Mitra de Santiago ${ }^{54}$. Aparece Manuel Cardelle ${ }^{55}$, veciño do lugar da Senra como propietario dunha "casa de torre con su cuarto, cocina, celeiro, horno, dos caballerizas arrimadas de costado de la casa y otra enfrente, y en medio el corral, de la parte de arriba la eira" $"$. Outro propietario era José Bravo, veciño do lugar de Senra de Cima da Vila, no que tiña "una casa tejada con su cuarto de torre, cocina, caballeriza, aira, corral y pajar en ella" 57 .

\section{III.3. Torre de Río}

Outra das torres edificadas no século XVI non tivo maior relevancia na historia social da terra de Rodeiro. Atopábase na freguesía de Santa María de Río, e foi construída, como xa veremos, sobre o 1570.

Estaba ligada á liñaxe dos Calviño, tan estendida polas terras próximas á fortaleza de Rodeiro. O primeiro que coñecemos desta familia é Pedro Calviño, vivo polo $1537^{58}$. Del naceu outro Pedro Calviño (tamén apelidado de Saa), que, como antes del o seu pai, ocupou moitos anos o cargo de cobrador "de las rentas, servicios y derechuras en Camba" 59 .

De este último foi fillo Juan Calviño Neto, que casou con María de Saa. Foron veciños do lugar de Barbeitos, en Santa María de Río, facéndolle ó matrimonio foro o Arcebispo de Santiago o 4 de marzo do 1567 do lugar de Vilamea, na mesma freguesía de Río. Nun apeo do 1576 figura o dito Juan Calviño como posuidor de "una casa grande donde vive el sobredicho con una torre blanca sobradada que el dicho Juan hizo"60.

A última noticia da liñaxe témola no fillo dos anteditos, chamado Domingo Calviño, que casou con Lucía Panadeiros e foron pais de Bartolomé Calviño ${ }^{61}$.

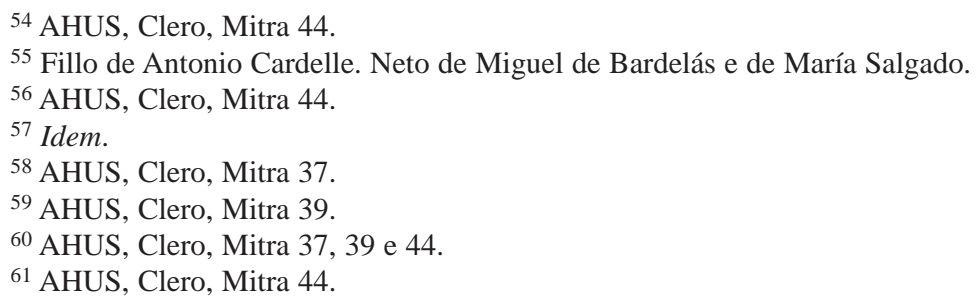




\section{III.4. Torre de Guillar}

A torre de Guillar na freguesía homónima, e un bo expoñente, aínda que reformado, das construccións representativas do poder fidalgo edificadas no século XVII, a imitación das estructuras defensivas doutros séculos pasados, posiblemente doutra existente con anterioridade que deu nome ó lugar.

De planta rectangular, as súas paredes de cantería duns dez metros de altura están coroadas por unha cheminea de sección trapezoidal, con gárgolas de desaugue. Así mesmo, outro elemento característico é a fiestra de esquina que aínda conserva (tapiada) na fachada oeste.

As primeiras mencións da torre de Guillar a relacionan con escribáns, concretamente con Alonso Vázquez de Pescoso e cos Araúxo que posuíron a escribanía de Camba e Rodeiro durante máis de dous séculos ${ }^{62}$.

Alonso Vázquez de Pescoso aparece como veciño do lugar da Torre, en Santa Mariña de Guillar, no 1576, cando era criado do escribán, xa citado, Juan González Becerra ${ }^{63}$. Actuou como escribán e notario público en Terra de Camba e Rodeiro no 1582 e 1597, vivindo na mesma Torre de Guillar ${ }^{64}$. Da súa familia debía ser Alberto Vázquez, escribán "del Rey Nuestro Señor" no 1605 e $1618^{65}$, dono da torre de Guillar, cónxuxe de Isabel de Novoa, así como o irmán do dito Alberto, o bacharel Alonso Vázquez de Temes, crego de Santa Mariña de Guillar e anexo ${ }^{66}$.

A outra liñaxe, a dos Araúxo, ten o seu primeiro referente en Pedro Rodríguez, veciño de Santa Mariña de Guillar, escribán "insolidum del Número y Audiencia del Juzgado de Camba y Rodeiro", oficio no que figura no 1591 e $1616^{67}$, tronco dunha longa saga que vinculou ás súas propiedades a escribanía de Número das xurisdiccións referidas. Entre eles, coas súas datas aproximadas de actuación, débense citar ós seguintes: Cristóbal Rodríguez de Araújo (1623-1628), Juan Rodríguez Araújo (1651-1667), Pedro Rodríguez de Araújo (1651-1674), Pedro Araújo e Somoza (1695-1709) ${ }^{68}$, José Araújo e Somoza (1724-1761) ${ }^{69}$, Manuel

\footnotetext{
${ }^{62}$ C. GÓMEZ BUXÁN, "Escribanos de Número en la comarca de Deza (s. XVI-XIX)". Anuarío de Estudios e Investigación Descubrindo, nº . 1, páxs. 175-200. Lalín, Seminario de Estudios de Deza, 1999.

${ }^{63}$ AHUS, Mitra 37.

${ }^{64}$ AHUS, Mitra 37, 43.

${ }^{65}$ Arquivo Histórico Provincial de Pontevedra (en adiante AHPP), índice de escribáns.

${ }^{66}$ Arquivo do autor.

${ }^{67}$ AHPP, índice de escribáns.

${ }^{68}$ Fillo do anterior. Veciño de Paredes, en Santa María de Álceme. AHUS, Clero, Mitra 43.

${ }^{69}$ Veciño de Álceme. AHPP, índice de escribáns.
} 


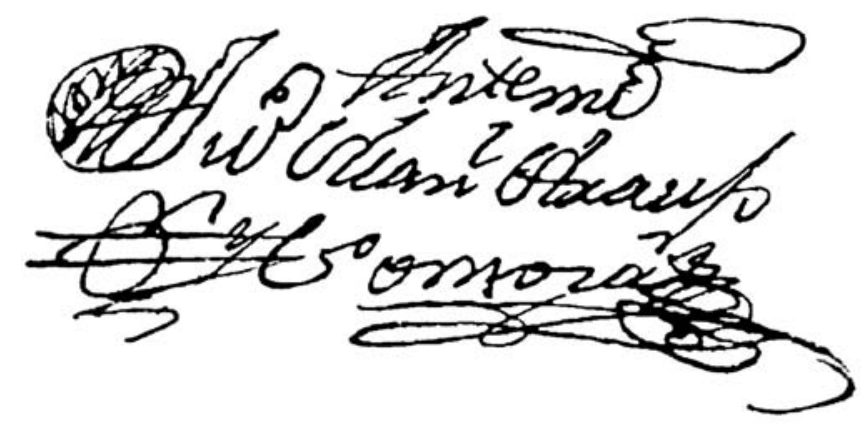

Figura 15: Sinatura dun dos escribáns de Guillar.

Araújo e Somoza (1743-1765), José Araújo e Somoza (1754-1760)ํㅜㄹ Juan Manuel Araújo e Somoza (1763-1790), don Francisco Araújo e Somoza (1791-1804), don Antonio Araújo e Somoza (1801-1817) ${ }^{71}$. Tamén da mesma familia debía ser descendente don José Benito Araújo e Somoza, alcalde de Rodeiro polo $1846^{72}$.

\section{OS FIDALGOS E OS PAZOS}

\section{IV.1. Os Oxea de Vilar do Fondo}

Ó abeiro das fortalezas medievais naceron moitas liñaxes fidalgas que noutros tempos inzaron as terras da Galiza. Escudeiros, escribáns, pequenos nobres, xente da compaña dos posuidores das fortificacións, recibiron foros de bens que constituíron centro de nacentes vínculos e morgados de casas importantes.

En Rodeiro, unha das principais foi a dos Oxea, apelido que procede de terras ourensás por entronque no século XVI.

O primeiro desta xenea asentada en Rodeiro foi Gil de Vence, que figura como tenente de xuíz na terra de Camba no 1543. Casou con Violante Vázquez ${ }^{73}$, e ó matrimonio fíxolle foro no 1537 o arcebispo de Santiago do lugar sito no Curral da

\footnotetext{
${ }^{70}$ Veciño de Paredes de Álceme, onde tiña, no 1760, unha casa con "dos cuartos o salas, cocina y subeira por el lado del norte patín de piedra, por el vendaval tendal y dos caballerizas, su portal grande y curro cerrado con era y pajar". AHUS, Clero, Mitra 43.

${ }^{71}$ Os datos anteriores extraídos de AHPP, índice de escribáns. Figura esta construcción estudiada en GÓMEZ e RUBIA, Op. cit., páxs. 281-286.

${ }^{72}$ AHPP, protocolos, Ca. 3072(2).

${ }^{73}$ Emparentada cos Cervela de Vilar do Fondo. Casou de segundas nupcias con Alonso d'Abonje. AHUS, Clero, Mitra 37.
} 
fortaleza de Rodeiro, polas súas vidas e dúas voces, en renda anual de cinco fanegas de pan e un carneiro ${ }^{74}$.

Da casa orixinaria no curral da fortaleza de Rodeiro consérvase unha descrición do $1714^{75}$, que se refire a ela como "la casa principal de dicho lugar de la villa que está en el fondo de el y se compone de cocina con su cuarto de sobrado debajo de un techo, maderada y cubierta de texa y colmo, con su chimenea de cantería en la cocina baja y paredes de mampostería antiguas con su escudo de armas en la puerta de abajo (en la cima del umbral)".

De Gil de Vence e Violante Vázquez naceu Gonzalo da Cervela, que figura como veciño de San Vicente de Rodeiro na década do 1570 . Faleceu no 1588 e a súa sepultura se atopaba na igrexa de San Miguel de Riobó ${ }^{76}$. Casou con Inés Pérez de Ulloa, e na seguinte xeración temos unha das imprecisións tan habituais na xenealoxía, e que no estado actual non podemos dilucidar, aínda que non podemos desbotar a solución destas incógnitas coa documentación que nun futuro se poida estudiar.

Temos constancia dun Pedro Ojea de Albán, posiblemente irmán ou familiar moi próximo deste Gonzalo da Cervela, que casou con Elvira Sánchez (irmá de Pedro López Varela, fundador do pazo de Trasulfe, filla por tanto dos señores do couto de Basadre, en terras de Agolada) ${ }^{77}$.

Fillo dos anteriores Gonzalo da Cervela e Inés Pérez de Ulloa foi Pedro Oxea de Albán, bautizado na igrexa de Riobó o 12 de xuño do $1585^{78}$. No 1609 figura como Capitán e veciño de San Vicente de Rodeiro e en 1615 de Vilar do Fondo, en Riobó.

Da pousa de Vilar do Fondo non se conserva practicamente nada na actualidade, trasladadas as súas pedras ó pazo de Cartelos (Carballedo - Lugo) a mediados do século XX. Tratábase dunha construcción de pequenas dimensións, con pequena escaleira exterior, grande cheminea rematada por pináculos ${ }^{79}$ e tres pedras armeiras, dúas de grande tamaño que se conservan nunha casa próxima, coas armas, entre outras liñaxes, dos Oxea, Varela, Ulloa, Temes, etc.

${ }^{74}$ AHUS, Clero, Mitra 42.

${ }^{75}$ AHUS, Clero, Mitra 43.

76 Segundo nos indica J. RAMÓN Y FERNÁNDEZ-OXEA, "Los Oxea. Su origen, sus armas". Cuadernos de Estudios Gallegos. Tomo XXX, 90-92, páxs. 109-132. Santiago de Compostela, Instituto de Estudios Gallegos "Padre Sarmiento", 1976-1977. Tamén cita a existencia doutra sepultura, pertencente a Gil Ojea, falecido no 1595, na que se atopaba a emblemática dos Oxea, é dicir, a aguia cos cinco crecentes e cinco luceiros (páx. 114-115).

${ }^{77}$ Arquivo do pazo de Trasulfe - Santiago de Fafián.

${ }^{78}$ Arquivo do pazo de Trasulfe. Outras informacións nos din que nacera no 1571 ou no 1576. En AHUS, Mitra 37 figura con vinte anos no 1596, e veciño de San Vicente de Rodeiro, e no mesmo arquivo (Mitra 44) tamén veciño da mesma vila de Rodeiro, capitán e con 38 anos no 1609.

${ }^{79}$ Hoxe empregados como remate dun hórreo na propiedade. 


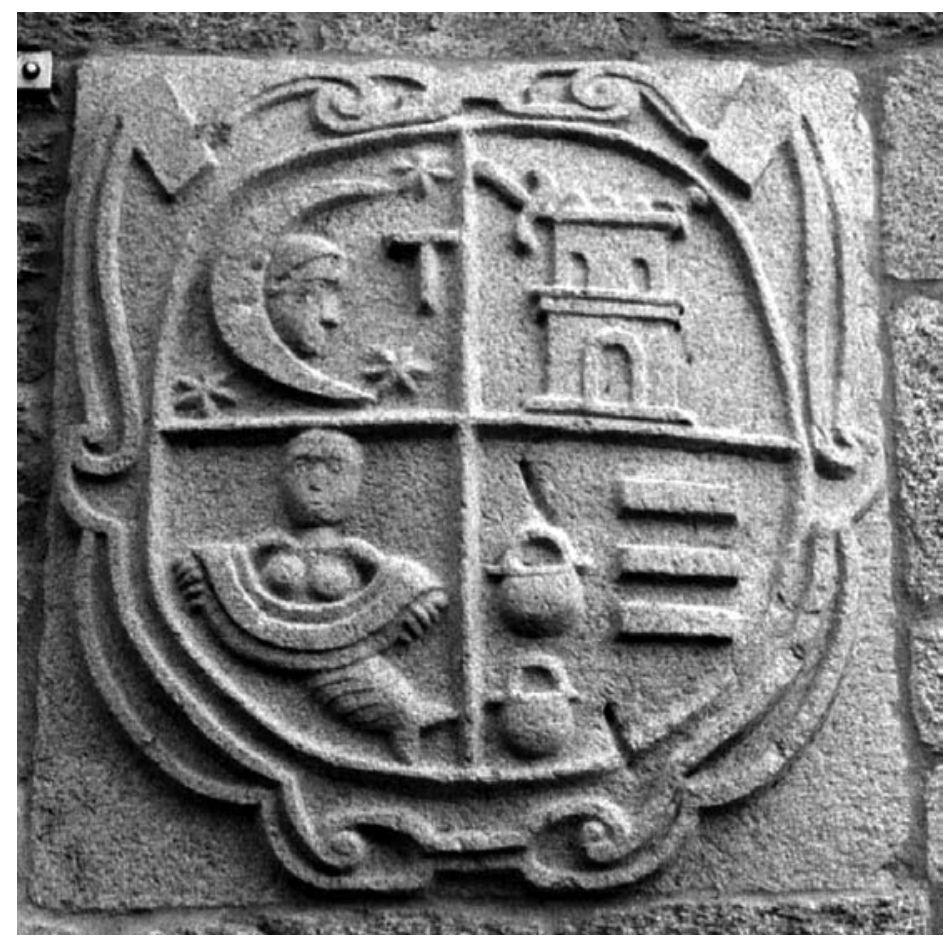

Figura 16: Pedra armeira con armas aínda sen determinar.

O citado capitán Pedro Ojea de Albán recibiu no 1621 do arcebispo de Santiago foro do lugar de Pena Herbosa por vida de tres reis, en renda anual de cinco fanegas de centeo, "un carnero bueno de año" e seis capóns cebados ${ }^{80}$. Casara con dona Isabel Taboada, oriúnda de Santa Mariña de Castro, filla de Gómez Vázquez e de Isabel Taboada ${ }^{81}$.

Do matrimonio quedou por herdeiro o Capitán Pedro Ojea de Ulloa Taboada, dono, por tanto, da "Pousa y casas de Vilar do Fondo". Fóra bautizado o 12 de decembro do 1612 na mesma pía bautismal de Riobó ${ }^{82}$. O 18 de agosto do 1646

${ }^{80}$ O 5 de abril do 1620 Gregorio de Castro cedeu o devandito lugar de Pena Herbosa ó capitán Pedro Oxea de Albán, en prezo de dez ducados. Así mesmo, o 23 de xullo do mesmo ano 1620 Marco de Castro fíxolle ó mesmo cesión "de la parte que le tocaba en dicho lugar de Pena Herbosa". AHUS, Clero, Mitra 42.

${ }^{81}$ Esta oriúnda tamén da terra de Deza, pois era filla de Gregorio Taboada e de Briolauja Mosquera, veciños de San Xoán de Vilanova, de ilustre ascendencia paterna e materna. AHUS, protocolos, 569 (sinatura antiga, pois estes protocolos non figuran actualmente no catálogo do arquivo).

82 RAMÓN Y FERNÁNDEZ-OXEA, Op. cit., páx. 121. 
figura subforando o dito lugar de Pena Herbosa en renda de vinteseis fanegas de centeo, doce galiñas, oito cuartillos de manteiga, dous carneiros e doce ducias de palla triga ${ }^{83}$.

Casou con dona Isabel de Ulloa Ribadeneira, a súa parente, como natural da casa de Quintela, en San Salvador de Asma, filla de don Benito Enríquez e de dona María de Ulloa. O Capitán Pedro Ojea testara no 1683, e do matrimonio quedaran por fillos Pedro Tomás, Gregorio, Gómez Benito ${ }^{84}$, Juan, Isabel, María, Constanza ${ }^{85}$ e Ángela Inés. O matrimonio fundou o vínculo e morgado da casa de Riobó, que pasou en primeiro termo a don Gregorio Oxea e Ulloa, e polo seu finamento sen descendencia ó seu irmán don Pedro Oxea.

Don Gregorio Oxea e Ulloa é un dos persoeiros de maior relevancia da casa, así como da historia da terra de Rodeiro. Sucesor no vínculo e morgado da casa de Riobó ${ }^{86}$, dono da xurisdicción das Balías de Bastaulfe e coutos a ela agregados. Deán e Cóengo de Lugo e Cabaleiro da Orde de Santiago ${ }^{87}$, exerceu importantes cargos, como o de Secretario da Cámara da Súa Maxestade e do seu Real Consello e da Suprema Inquisición de Madrid ${ }^{88}$. O 3 de xullo do $1696^{89}$, ante o escribán Clemente Bringas o "señor don Gregorio Oxea y Ulloa, Caballero del Orden de Santiago, Secretario del Rey Nuestro Señor y de su Consejo de la Santa y General Inquisición, dueño de la Casa y lugar de Rioboo, en San Miguel de Rioboo, y señor de la jurisdicción de Baleas de Bestaulfe y

\footnotetext{
${ }^{83}$ Como vemos, o aumento de renda é importante en comparación co foro orixinal.

${ }^{84}$ Cóengo de Santiago no 1683. Entre a parentela citada nas probas figuran o seu curmán carnal don Benito Enríquez, Cabaleiro de Santiago e señor da casa de Quintela; D. Rodrigo Antonio Falcón e Ulloa, curmán segundo del, tamén Cabaleiro de Santiago, como tamén o era don Alonso Ulloa Rivadeneyra, curmán da nai desta irmandade. Entre outros parentes figuran os Comisarios do Santo Oficio, don Jerónimo de Ulloa, don Pedro de Moure y Ulloa, Abade de Chantada, don Jorge Taboada, abade de Refoxos, e o Doctor don Pedro Fernández de Parga, consultor do Tribunal de Inquisición, cóengo doctoral de Santiago, e don Gregorio Enríquez de Somoza, cóengo de León e Toledo. P. PÉREZ COSTANTI, Linajes galicianos, ed. completa e ampliada de Eduardo Pardo de Guevara y Valdés, Santiago de Compostela, Ara Solis - Consorcio de Santiago, 1998, páx. 270.

${ }^{85}$ Nacida o 10 de novembro do 1652. Casou con Francisco Mosquera, dono da Casa de Vilariño ou Torre Pazo (fillo de Gabriel Mosquera e Andrade e Soutomaior e de María Mesa). Como o número de fillos, datos extraídos de V. DE CADENAS Y VICENT, Caballeros de la Orden de Santiago. Siglo XVIII. Tomo IV, Madrid, Ediciones Hidalguía, 1979, nº. 1215, año 1751, sig. 5.584 .

${ }^{86}$ A ela estaba anexa a casa principal do Corral da fortaleza de Rodeiro, á que nos referimos anteriormente.

${ }^{87}$ Creado cabaleiro de Santiago o 28 de abril de 1681, xunto co seu irmán don Pedro Tomás.

${ }^{88}$ AHUS, Clero, Mitra 43, 44.

${ }^{89}$ AHUS, Clero, Mitra 42.
} 
cotos a ella agregados, residente en la Villa y Corte de Madrid", outorga poder ó seu parente don Rodrigo Antonio Falcón de Ulloa e Sotomayor, marqués de Bendaña, cabaleiro de Santiago, a don Gómez Benito Ojea, irmán do outorgante, cóengo cardeal da igrexa de Santiago, e a don Diego Piñeiro de Ulloa e a don Antonio Fariña, cóengos da igrexa de Santiago, e a don Juan de Orrea, Nuncio xubilado da Inquisición de Sevilla, para que no seu nome puideran solicitar a frei Antonio de Monroy, arcebispo de Santiago, que lle fixera ó outorgante feudo ou foro da xurisdicción "civil y criminal, mero, mixto imperio de dicha casa y lugar de Rioboo, para él y sus herederos".

O 4 de xullo do 1697 o dito arcebispo frei Antonio de Monroy, ante o escribán Domingo Antonio de Caamaño, fíxolle foro da citada xurisdicción de Riobó, pola vida de tres reis, en canon de "un marco de plata vieja, que vale ocho onzas", pago polo 25 de xullo de cada ano. Esta casa e xurisdicción se limitaba do seguinte xeito: "confina por la parte del norte con el camino que viene del Pontillón del río Arnego y pasa hasta el Outeiro y de él prosigue por la parte de levante por el camino que va a la feligresía de San Esteban de Carboentes y por la parte de vendaval demarca con los montes de dicha feligresía de Carboentes, bajando a dicho río Arnego, y desde allí por el poniente pasa por la presa que viene al sitio de la Barga y Batán viejo, y remata en dicho Pontillón, donde cierran dichas demarcaciones" 90 .

Faleceu don Gregorio sen sucesión, pasando os morgados á descendencia do seu irmán don Pedro Oxea Vázquez Baamonde, cabaleiro de Santiago, que nas sucesivas xeracións engadiu o dominio do pazo de Santa Mariña do Castro e o título de Conde da Torre Penela ${ }^{91}$.

\section{IV.2. Casas de Faílde e Fornas}

Outro dos típicos exemplos das antigas pousas ou casas grandes é a casa de Salto, habitada aínda polos descendentes da liñaxe. A súa estructura actual, unha ampla construcción de planta rectangular con capela incluída no edificio (identificable polo campanil que sobresae do tellado), escaleira de acceso á planta nobre e corredor lousado de cantería na fachada do mediodía.

${ }^{90}$ AHUS, Clero, Mitra 42.

91 Título concedido en 31 de outubro de 1689 a prol de este don Pedro Ojea de Ulloa. Elenco de Grandezas.., páx. 876. Para máis informacións ver, por exemplo, GÓMEZ e RUBIA: Op. cit., páxs. 287-290. 


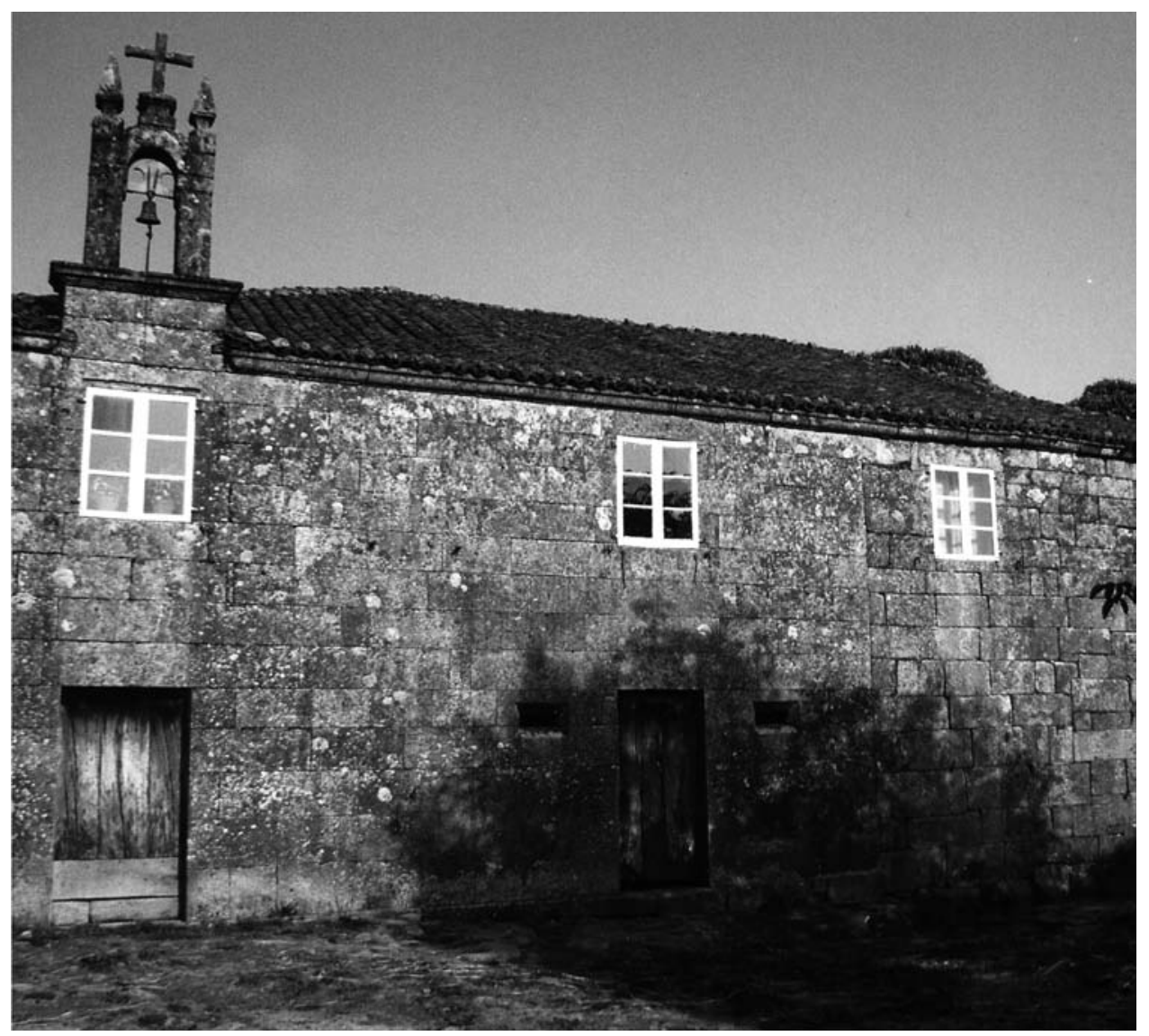

Figura 17: Fachada co campanil da capela.

O máis destacable da casa de Faílde son as dúas pedras armeiras que campan na fachada que da ó alpendre. Unha delas coas armas dos Varela e Ulloa. E o outro trae no primeiro cuartel as armas dos Taboada e no resto dos cuarteis outras liñaxes non identificadas.

Dos primeiros habitantes foi Alonso Vázquez Varela, no século XVI, descendente da casa de Quindimil, en Palas de Rei ${ }^{92}$, casado con Catalina Sánchez da Somoza, da Casa Grande de Cercio.

92 Para algunhas informacións sobre a casa de Quindimil ver, por exemplo, C. GÓMEZ BUXÁN, "Debuxos do Melide de hai tres séculos. Descrición e notas heráldicas". Boletín do Centro de Estudios Melidenses, 19, Melide, 2006, páxs. 95-110. Tamén do mesmo autor "A Casa de Quindimil nun testamento do século XVI". Lvcensia, nº. 35, Lugo, Biblioteca del Seminario Diocesano, páxs. 291-300. 


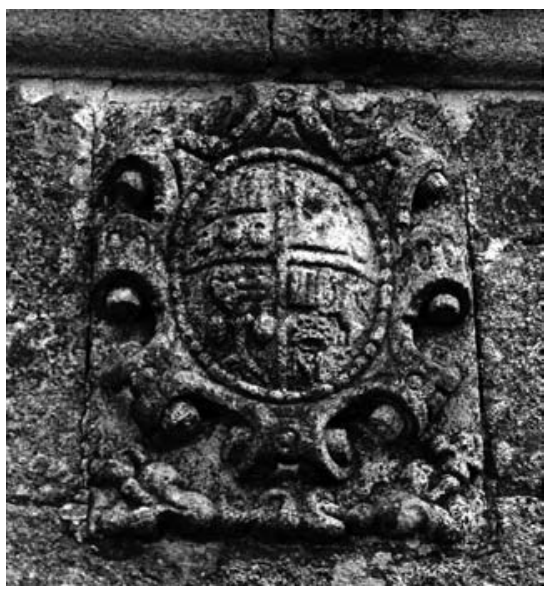

Figura 18: Labra coas armas dos Taboada e outras.

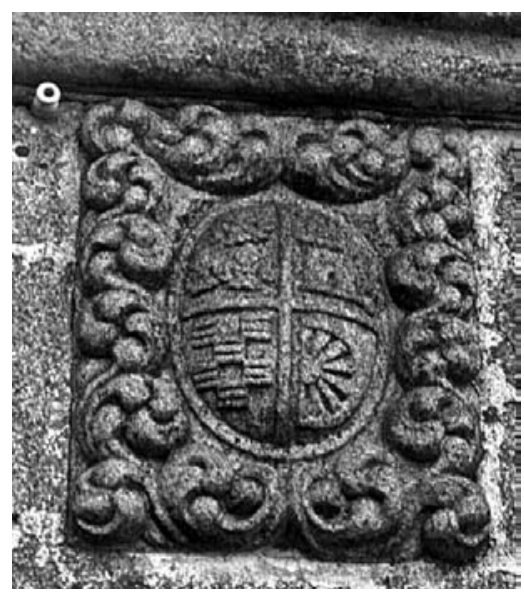

Figura 19: Armas dos Varela noutra armería.

Pasou despois á liñaxe dos Faílde, a comezos do século XVII. Un dos primeiros é Pedro Faílde, casado con Susana López. O seu fillo, Juan López Faílde, natural de Santo Estevo do Salto, casou con Catalina Vázquez de Aguiar, oriúnda de Santa Mariña de Pescoso, e deles naceu o alférez Pedro López de Faílde.

Deste último e da súa muller Beatriz Vázquez Varela foi sucesor o licenciado Bentura López de Faílde, avogado da Real Audiencia do Reino da Galiza. Tamén licenciado era o seu irmán Antonio López Faílde, e outro, Mauro López Faílde foi Colexial de Fonseca e cura de Santa Susana de Arcai primeiro e de Santa María de Isorna máis tarde ${ }^{93}$.

O licenciado Bentura López de Faílde casou con dona Rosa Varela ${ }^{94}$, herdándoos don José López Faílde e Varela, que exerceu como xuíz da xurisdicción de Camba, cargo no que figura no 1777. A súa muller, dona Josefa Araújo, era filla de Andrés Panadeiros e de dona Rosa Araújo, veciños de Santo Estebo de Carboentes.

Os sucesores deste matrimonio seguiron na posesión da casa de Salto, transmitindo o apelido Faílde nas sucesivas xeracións, ata o século XIX, no que se perde, por recae-la sucesión en muller, concretamente nunha filla de don José Faílde, chamada dona Carmen Faílde Tojo, sobriña do licenciado don Benito Faílde Ribadeneira, deán da Catedral de Tui.

93 Fora bautizado o 25 de marzo do 1673, cura de Santa Susana de Arcai desde o 13 de abril do 1707, pasando despois ó curato de Santa María de Isorna, onde finou no 1717.

94 Era filla de Pascual Diéguez de Aguiar e de dona Juana Varela e Saavedra (esta do pazo de Beilás, en San Miguel de Goiás), veciños de Santa Mariña de Pescoso. 


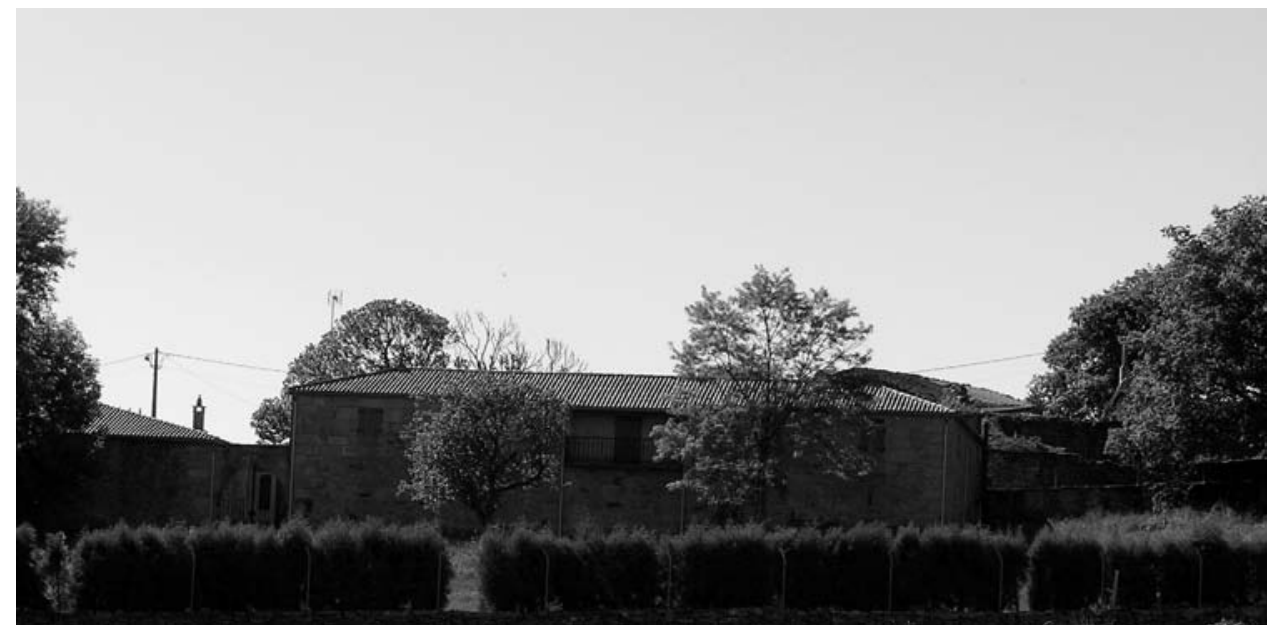

Figura 20: A casa de Vales de Fornas.

A dita dona Carmen casou na casa de Vales de Fornas, grande construcción que conserva pombal e un grande portalón de entrada.

Foi fillo desta casa don Francisco Javier Vales Faílde, persoeiro ilustre das terras de Rodeiro. No 1898 é nomeado Vicario Xeral e catedrático no Seminario de Madrid, no 1914 auditor do Tribunal da Rota, membro da Real Academia de Ciencias Morales y Políticas e da de Jurisprudencia. Capelán de Alfonso XIII, receptor da Real Capela e, por tanto, confesor real, foi proposto para bispo de Sión, vicario xeneral castrense e patriarca das Indias, promoción que impediu o seu prematuro finamento o 30 de marzo do $1923^{95}$.

\section{IV.3. Pazo de Trasulfe}

Estamos ante un dos mellores expoñentes da arquitectura pacega da terra de Camba. Elementos como o portalón armoriado e a fermosa balconada fan da súa imaxe unha fermosa estampa de poder e fidalguía.

O primeiro punto de interese é o impresionante, por armoriado, acceso ó patio ou curral. Nun lenzo no que se abre un arco de medio punto, campan cinco pedras armeiras, tres delas nas doelas do arco, relativas as liñaxes dos López, Taboada, Varela e Ulloa,

${ }^{95}$ Datos sobre esta familia en GÓMEZ e RUBIA: Op. cit., páxs. 291-296. Tamén en R. C. LOIS CALVIÑO, "Manuel García Gil e Francisco Javier Vales Faílde: dous membros do alto clero nados na parroquia de San Salvador de Camba". Anuario de Estudios e Investigación Descubrindo, no. 2, páxs. 115-130. Seminario de Estudios de Deza, Lalín, 2000. 


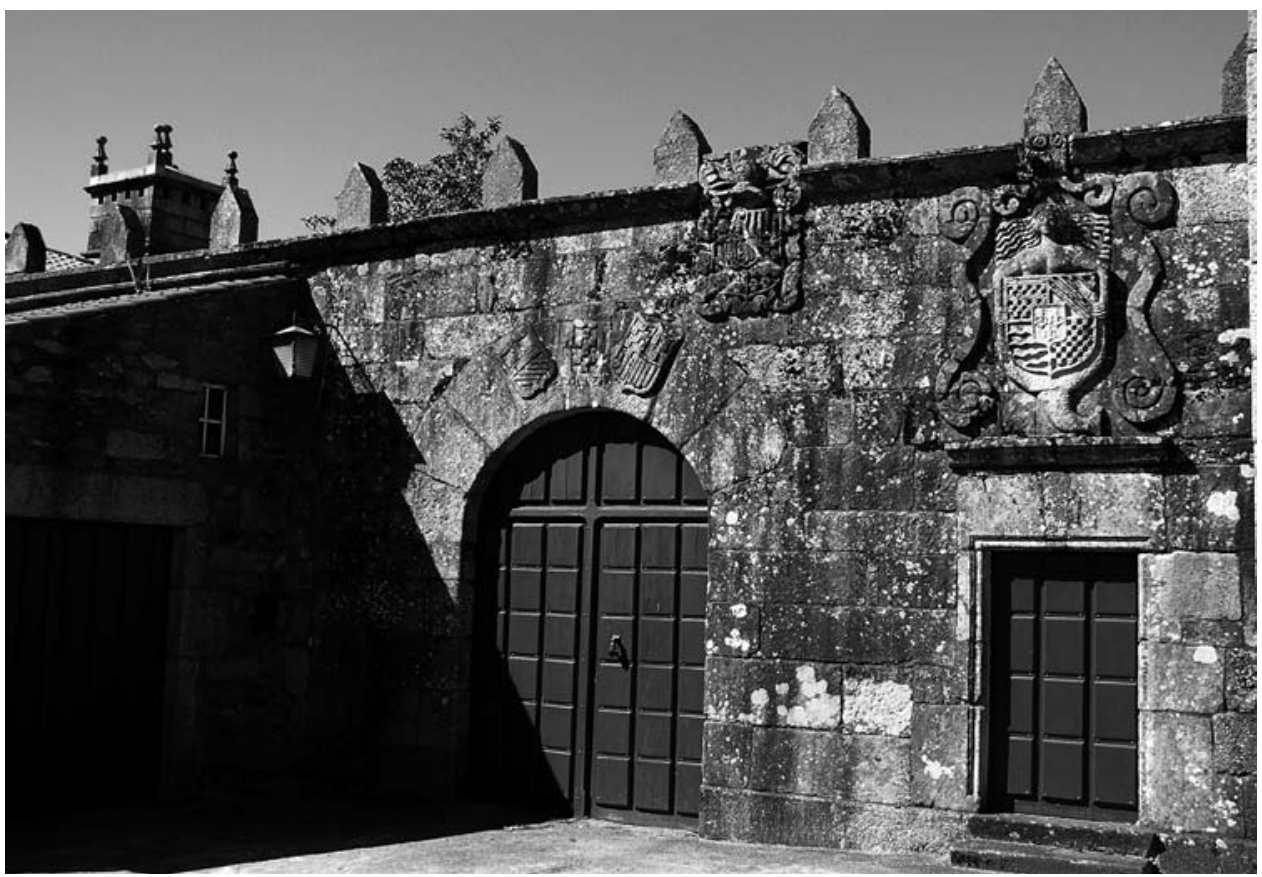

Figura 21: A magnífica entrada de Trasulfe con cinco pedras armeiras.

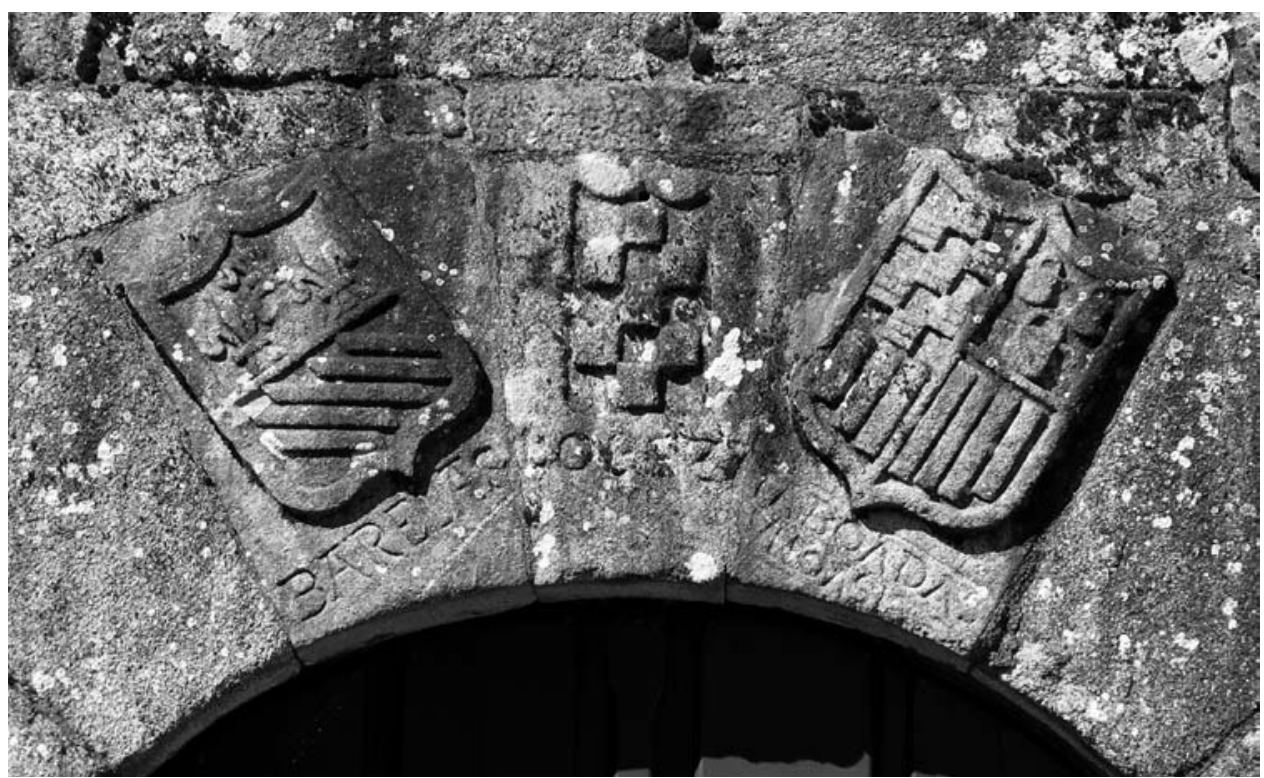

Figura 22: Armas dos “Barelas”, López, Taboada e Ulloa, de finais do século XVI. 
datan posiblemente de finais do século XVI, e fan referencia ó matrimonio fundador do vínculo e morgado de Trasulfe: Pedro López Varela de Dubra e a súa segunda muller Sancha Álvarez de Baamonde e Taboada. As outras dúas, máis recentes, de finais do XVII unha delas e a outra do XVIII traen armas dos Taboada, Varela, Arias, etc.

No interior, no curral enmarcado polo edificio, a capela e un amplo cuberto, atopamos outras dúas pedras armeiras posiblemente do século XVII que reproducen as armas do portalón de entrada, un deles co xaquelado dos López, e o outro cuartelado en cruz cos López de Lemos e Varela.

Outra das fachadas de maior interese é a de poñente, cunha grande balconada, miradoiro de excepción da terra de Camba, montada en voado. Tamén destacan os xardíns e o pombal dentro da cerca murada que rodea a propiedade.

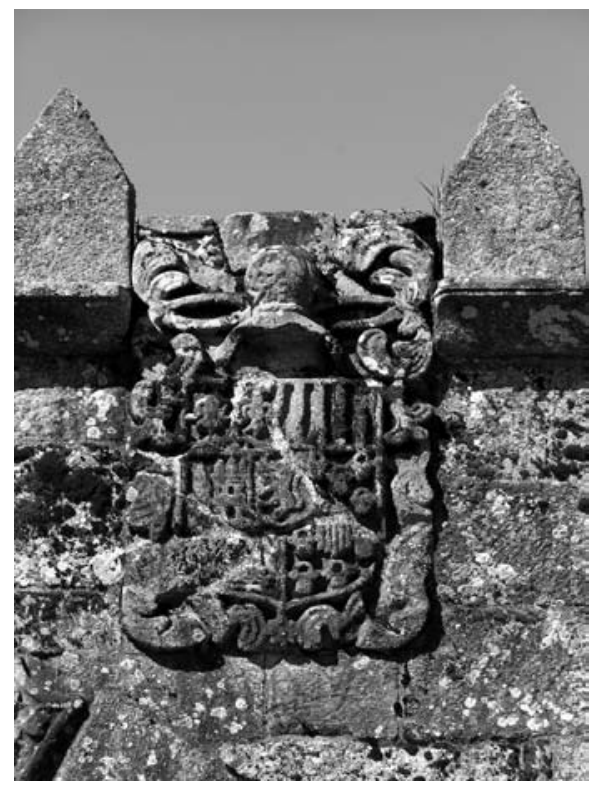

Figura 23: Armas dos Varela, Churruchaos e Taboada.

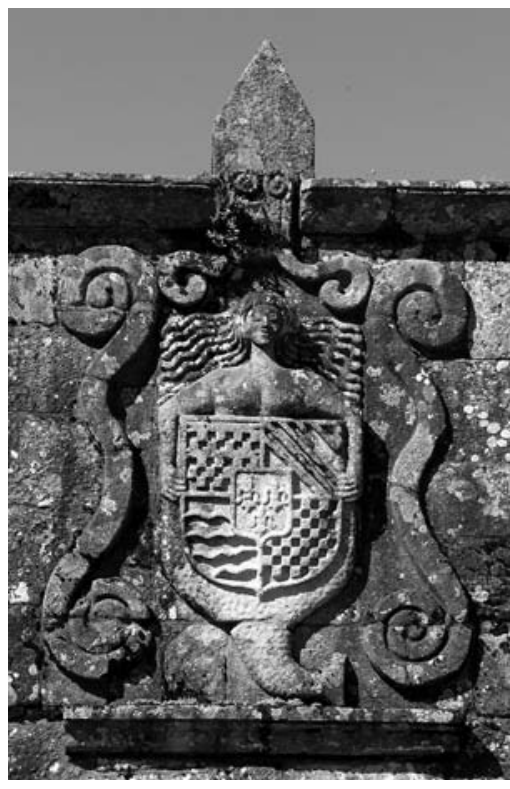

Figura 24: Gran armería barroca alusiva ó entronque cos Mariño.

A historia coñecida do pazo comeza no século XVI, cando o lugar de Trasulfe estaba dividido entre uns labradores veciños de Sa, en Santa Mariña de Pescoso, e o "señor" Galaor Taboada López de Lemos, dono do couto de Orbán. Coa primeira metade fíxose por doazón Pedro López Varela, oriúndo da casa de Basadre, cando estaba casado coa súa primeira muller Constanza Rodríguez da Cervela, procedente da 
casa dos Oxea na vila de Rodeiro. A segunda metade tamén pasou á súa propiedade ó casar en segundas nupcias este Pedro Varela con Sancha Álvarez de Baamonde e Taboada, neta do devandito Galaor Taboada, posuidora desta parte do lugar de Trasulfe.

Este segundo matrimonio fundou o vínculo e morgado de Trasulfe no 1595, no que se incluía a "pousa de Trasulfe y el coto de Oyra con su jurisdicción civil y criminal". Casaran no 1569, e o sucesor na pousa foi Gregorio López Varela de Ulloa ${ }^{96}$.

$\mathrm{Na}$ descendencia deste connubio entre este Gregorio López e Antonia López Mosquera, a súa parente, segue a posesión da antiga pousa de Trasulfe, ata a súa terceira neta, dona María Andrea Varela, coa que desaparece da liña o apelido Varela que se mantiña desde había dous séculos.

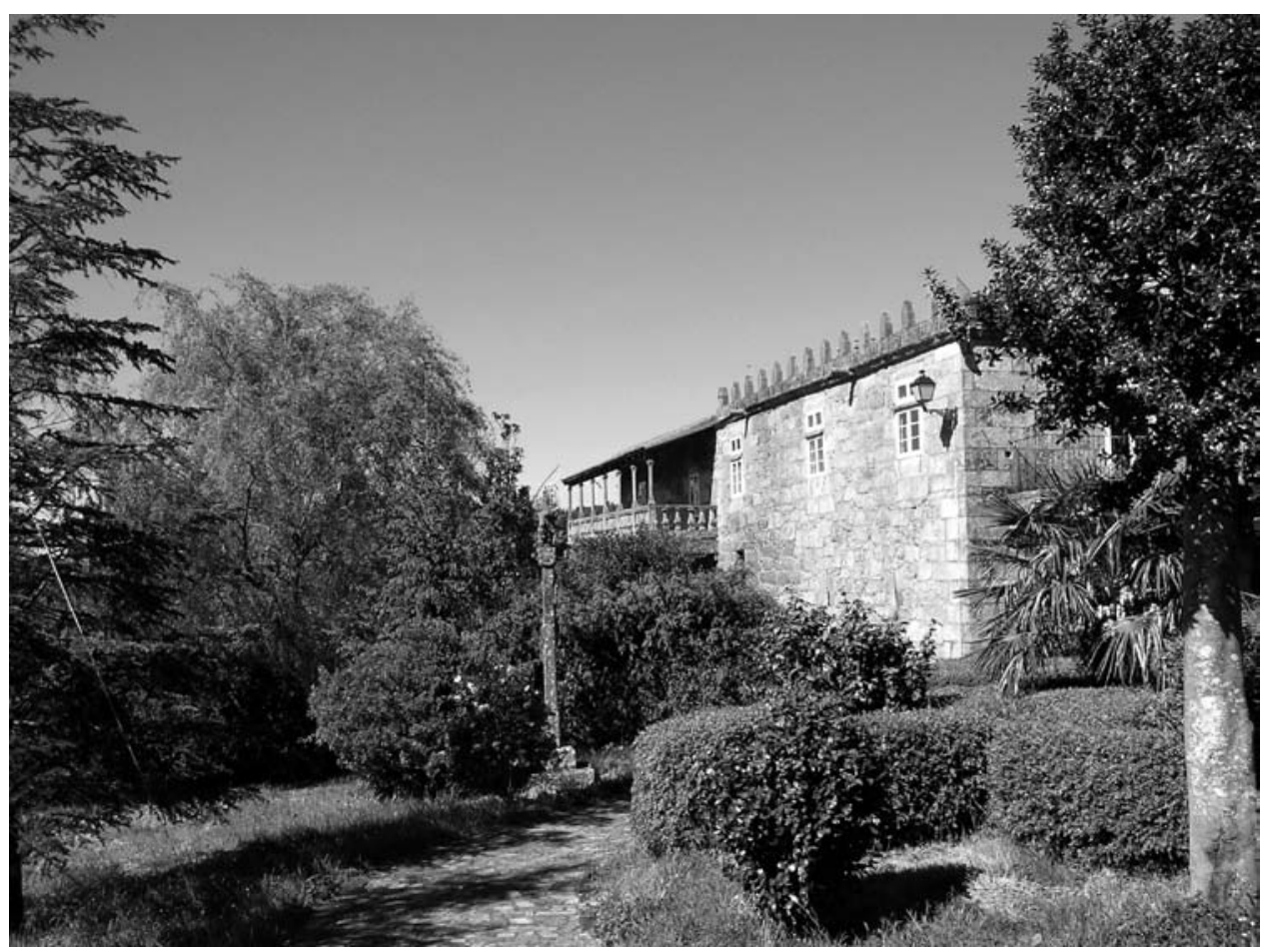

Figura 25: Fachada posterior, xardín e balconada cuberta do pazo de Trasulfe.

96 Do primeiro matrimonio naceran: María Varela, casada con Manuel de Toubes, señor do couto de Cristimil, de primeiras nupcias, e de segundas con Esteban Bermúdez; Violante Varela, muller de Andrés Sánchez, dono da casa de Cercio; e Pedro López Varela, escribán de Número de Deza nos primeiros anos do século XVII. Do segundo enlace coa citada Sancha Álvarez de Baamonde naceron entre outros: Gregorio, sucesor en Trasulfe; Fernando López Varela, da casa de Mera, en Basadre; Lope Sánchez de Ulloa, escribán de Número e Audiencia de Terra de Deza de 1614 a 1643 . Arquivo do autor. 
O cónxuxe de dona María Andrea foi don Joaquín Ventura Arias Mariño de Losada, herdeiro das casas de Saa (en Sadornín) e do couto de Vilariño, en Beade, ós que sucedeu o Maestrante da Real Cabalería de Ronda don José Gregorio Arias Varela, o seu fillo, manténdose a liña nas xeracións sucesivas ata chegar á época actual, na que segue a liñaxe dos Arias como donos de Trasulfe, na persoa dos herdeiros de don Jaime Enrique Arias Campo, recentemente finado, receptor de catro séculos de historia ${ }^{97}$.

\section{CONCLUSIÓN}

O protagonismo da liñaxe dos Rodeiro, que nos séculos da Idade Media tiveron o seu feudo na homónima xurisdicción hoxe englobada na comarca de Deza, deixou paso, como na maior parte da Galiza, a unha fidalguía de variable poderío económico, que foi cubrindo o nicho de poder ocupado anteriormente polas antigas familias dos séculos XII a XIV. Desde logo, a referencia en todos os períodos, tanto nos séculos centrais da Idade Media como en tempos máis modernos, a constitúen as dúas fortalezas, Rodeiro e Camba, e máis adiante o pazo de Trasulfe, o mellor representante destas construccións fidalgas no actual concello.

Nembargantes, un percorrido breve como o presente, só pode deixar de manifesto o inexorable paso do tempo para a maior parte destes elementos, testemuñas do poder da nobreza en séculos pasados. As noutrora abondosas fidalgas construccións que aparecían espalladas polo concello de Rodeiro van pouco a pouco desaparecendo, algunha aínda agoniante, perdéndose tamén, se é que ninguén toma medidas para remediar a súa perda, a súa heráldica, os seus arquivos, e incluso a memoria de que nalgún tempo existiron, perdéndose con elas unha parcela importante da nosa historia.

${ }^{97}$ GÓMEZ e RUBIA: Op. cit., páxs. 263-274. 